\title{
The Impact of Tax Credits on Labor Supply
}

\author{
Ghazala Azmat* \\ University Pompeu Fabra
}

July 2009

\begin{abstract}
One of the principle aims of the Working Families' Tax Credit in the UK was to increase the participation of single mothers. The literature to date concludes there was approximately a five-percentage-point increase in employment of single mothers. The differences-in-differences methodology that is typically used compares single mother with single women without children. However, the characteristics of these groups are very different, and change over time in relative covariates are likely to violate the identifying assumption. We find that when we control for differential trends between women with and without children, the employment effect of the policy falls significantly. Moreover, the effect is borne solely by those working full-time (30 hours or more), while having no effect on inducing people into the labor market from inactivity. Looking closely at important covariates over time, we can see sizeable changes in the relative returns to employment between the treatment and control groups.

JEL classification: H24, I38, C14, J22.

Keywords:Tax Credits, Differences-in-differences, Single Mothers.
\end{abstract}

${ }^{*}$ Department of Economics and Business, University Pompeu Fabra, Ramon Trias Fargas 25-27, 08005 Barcelona, Spain. Email: ghazala.azmat@upf.edu, Tel.: +34-93542-1757, Fax: +34-93542-1766. 


\section{Introduction}

In October 1999, the Working Families' Tax Credit (WFTC) was introduced in the United Kingdom with the intention of "making work pay" for families with children. This so-called "in-work benefit" aimed to encourage certain groups in the economy-single parents and low-income couples-to participate in the labor market. In general, WFTC aimed to alleviate poverty at the lower end of the wage distribution, reduce income inequality and redistribute income by reducing the dispersion of earnings.

The WFTC was a minimum-working-hours based credit for families with children, and although it was not an innovative policy, it was much more generous than its predecessor, Family Credit, and extended further up the wage distribution. Spending on WFTC totaled $£ 6.3$ billion in 2002/03 compared with only £2.3 billion under Family Credit in 1998/9. Eligibility for WFTC was contingent on four criteria: household members working a minimum of 16 hours a week; the presence of children; "low" household income; and financial assets below $£ 8,000 .{ }^{1}$ Although the amount of WFTC varied a great deal with the number and ages of the children, on average, a single-parent household received $£ 91.98$ per week in 2002 , compared with $£ 59.48$ per week in 1998 , while coupled households received, on average, $£ 80.79$ per week in 2002 , compared with $£ 59.15$ per week in $1998 .^{2}$

The magnitude and the popularity of this tax-credit policy induced a number of studies on the labor-supply impact of WFTC (see Brewer and Browne (2006) for an overview of the literature). The overall conclusion was that the generosity of the in-work credit system was successful in inducing single mothers to increase their participation in the labor market by five percentage points. The labormarket impact of WFTC on single parents (particularly, single mothers) is important to understand as they were one of the biggest beneficiaries of the tax-credit policy. The government targeted this particular group as it became apparent that there was a shift in the composition of the lowest decile of the income distribution from pensioners to families of working age, and single parents in particular (see Goodman (2001)). Figure 1 highlights the differences in income between different family types. Moreover, by looking at the cross-country employment rates of single mothers in Figure 2, it is clear

\footnotetext{
${ }^{1}$ In October 1999, families with a net income below $£ 92.90$ a week recieved the maximum amount of WFTC, and it would then taper off to 55 percent.

${ }^{2}$ These figures are taken from the "Working Families' Tax Credit Statistics," Inland Revenue Quarterly Enquiry $(2003)$
} 
that the UK has one of the lowest.

A common approach for analyzing the impact of tax-credit policies on the labor supply of single mothers (for example, Eissa and Leibman (1996)) has been to use the differences-in-differences methodology. Using this approach, single women without children are used as a control group and compared, before and after the policy introduction, to single mothers (the treatment group). This technique relies on the assumption that the comparison group is a sufficiently close match and that the relative returns to covariates remain similar over time, such that after taking the differences-indifferences, the remaining effect can be considered as the impact of the policy alone on the treated group. However, it is quite likely that single women without children are not an appropriate control group since they are observably and (most likely) unobservably different. Moreover, in the case of the UK, the pattern of employment growth over time for single women without children has been very different from the patterns for those with children. Figure 3 plots the employment rates of single women without children and single mothers. ${ }^{3}$ We can see that there has been an increasing trend in the employment rate of single mothers since the mid-1990s, while the level for single childless women has been high and has remained fairly flat over the same period. In particular, over the period 1996 to 1999 (the "pre-treatment" period), employment rates increase by 6.5 percent for single mothers and only 1.6 percent for single childless women. Given these patterns, we may also infer that the composition of single mothers has been changing over time, making a comparison between these two groups even more difficult. From this, we may be concerned that the labor-supply estimates of the policy effect are somewhat upward-biased. Moreover, there was no noticeable spike with the introduction of WFTC. After 2000, increases in employment of single women flattened, despite increases in the basic tax credit each year from 2000 to 2003. In particular, on introduction in 1999, the basic rate was $£ 52.30$ per week and increased to $£ 65.50$ per week by April 2002; however, employment rates for single mothers increased by only 0.8 percent during that period.

In addition to the overall employment effects of WFTC, we may also be interested in the distribution of hours worked and the transitions into employment from various labor-market states. Since WFTC was contingent on working at least 16 hours a week, we may expect there to have been a spike

\footnotetext{
${ }^{3}$ Our analysis stops in 2003, as WFTC was replaced by the Working Tax Credit.
} 
after 1999 at the 16-hours point. In addition, since the policy offered a bonus if the claimant worked 30 hours or more, we may expect some change here too. However, if we look at the hours distribution of single mothers in Figure 4a, the "post-treatment" (2000-2003) increases in hours worked beyond at the 16 hour point are very small but, more notably, continuous over the whole time period. The changes in hours worked can be seen more clearly in Figures 5a to 5c. While fewer single mothers worked 0-15 hours and more worked 16-29 hours, these patterns have occurred smoothly since the mid-1990s, with no spikes when WFTC was introduced. ${ }^{4}$

The aim of this paper is three-fold: first, to address the concern of the suitability of the control group to see how the results change when we control for group-specific differential trends; second, to see where (along the hours distribution) the changes in the employment of single mothers took place and from which labor-market state (working 0-15 hours, unemployment,or inactive); finally, we look at the time-series movements of the relative rates of return of important covariates to employment-in particular, returns to the presence of children (i.e., the treatment variable) between 1993 and 2003. Overall, when we allow for differential trends, we find that the effect of WFTC on employment falls to 1.7 percentage points, considerably lower than the literature's estimate of five percentage points. We find that this effect is borne solely by those working full-time (30 hours or more). In addition, we find that the policy change had no effect on those who were inactive. The analysis on the covariates confirms that there has been a continuous fall in the relative difference between having children and not having children on the probability of entering into employment. The relative differences in other important covariates, such as education, have also been changing over time.

These results offer valuable insight into two key issues: first, the effectiveness of policy and second, the design of the policy. In particular, they imply that the increase in participation is overestimated using standard techniques. Moreover, the policy was not as well targeted as initially believed, given that any increase in employment was borne solely by those who work 30 or more hours, while those who were inactive were unaffected by the policy.

The rest of the paper is structured as follows: Section 2 gives a brief description of the tax-credit reform. Section 3 discusses the difference-in-difference methodology and describes initial concerns

\footnotetext{
${ }^{4}$ See Table A1, which shows more clearly the movements in the hours distribution over time.
} 
with regard to both the treatment and control groups. In Section 4, we discuss the data and main descriptive statistics of the treatment and control groups. Section 5 we estimate the effect of WFTC on employment and hours. In Section 6, we continue our evaluation of WFTC by looking at the movements in coefficients over time. Section 7 discusses the implications of these results and tries to understand why we observed the increases in single mothers' employment rates before WFTC. Section 8 concludes.

\section{The Structure of the WFTC Reform}

In this section, we briefly describe the Working Families' Tax Credit (WFTC) policy, introduced in the UK in October 1999.

Systems of support for families with dependent children in the UK have been in operation since the 1970s. Although there were some structural reforms over the years, the eligibility criteria have generally been based on a family income below a certain level, the presence of children and a low household savings rate. There were two distinctive differences between its predecessor, Family Credit (FC), and WFTC. First, the WFTC was much more generous, exceeding the FC in four ways: an increase in the credit for children under age 11 from $£ 12.35$ to $£ 14.85$ per week (per child); an increase in the threshold from $£ 79$ to $£ 92.90$ per week; a reduction in the taper from 70 percent to 55 percent and a childcare credit of 70 percent of actual childcare costs up to $£ 150$ per week. Figure 6 shows these relative changes. It can be seen that those who would gain the most were people who were just at the end of the taper under FC, as they were previously ineligible and were now eligible. In addition, those with a net income between $£ 79$ and $£ 92.90$ per week would move from being on the taper to receiving maximum support, and those who remain on the taper following the introduction of WFTC would see their withdrawal rate fall from 70 percent to 55 percent.

The second important difference between Family Credit and WFTC was that the WFTC payment was made through the wage packet. This was an attractive move because it became more convenient to distribute and reduced the "welfare benefit" stigma attached to the tax credit. In April 2000, the eligible claimant would claim the approximate tax credit from the Inland Revenue, which would work 
out the amount of tax credit payable. The Inland Revenue would then notify the relevant employer of the amount of tax credit to be paid, and the employer would pay the tax credit out of the tax and National Insurance contribution that they would otherwise have forwarded to the Inland Revenue.

\section{Difference-in-difference Estimation}

\subsection{The Treatment Group: Single Mothers}

The number of single parents increased from 0.5 million in the early 1970 s to 1.5 million by 1997 , representing 25 percent of all families with children (see McKnight (2005)). However, this rise in the number of single parents was coupled with a fall in the employment rate of this group from 50 percent to 40 percent over a similar period. Some of these changes were attributed to changes in composition and to demographic factors. Overall, the number of workless households rose to 3.2 million by 1997, accounting for 18 percent of the working-age households. Approximately a quarter were single-parent households (see Gregg \& Harkness (2003)), making them a target group for government support.

The introduction of WFTC was designed to tackle the lack of work incentive within this group. The tax-credit policy offered a financial incentive for parents to find and remain in employment for over 16 hours a week. The structure of the tax credit was such that it incorporated a basic tax credit of $£ 62.50$ (in 2002/3) for those working more than 16 hours, plus an additional supplement per child (£26.45 for children aged under 16 and $£ 27.20$ for those aged 16-18). Overall, WFTC increased the average benefit payable to single parents from $£ 58$ a week in 1997 to $£ 92$ by 2002 . By $2002,737,000$ single parents claimed WFTC, compared with only 341,400 receiving Family Credit in 1997. Since the majority of these single parents were women, our focus will be on single mothers.

Figure 7 shows how WFTC changed the budget constraint of a single mother with one child. The reform unambiguously enhanced the probability of participation, as the financial returns to working more than 16 hours were greater after the reform. However, the complexity of the budget constraint and the interaction with other taxes and benefits imply that the overall impact of WFTC on the labor participation of single mothers is not entirely obvious. Blundell et al (2000) highlight that the 
increase in net income was small for those who worked fewer than 25 hours a week because of the interaction of WFTC and the Housing Benefit. For higher levels of hours worked, the reduction in the WFTC taper increases the returns to working. For those already working, the labor supply response to the introduction of WFTC is unclear because the marginal tax rate was unambiguously reduced at all hours under the reform, though even with WFTC, it remained high (70 percent). This increased the price of non-market time, causing individuals to consume less non-market time and, therefore, to increase their hours of work (standard substitution effect). The income effect would be negative, however (assuming that non-market time is a normal good).

In Figure 8, we see the evolution of employment rates among single mothers. It can be seen that between 1992 and 2002, the employment rate increased from 42 percent to 53 percent and that there was no obvious spike after October 1999, which would allow us to attribute the increase in labor supply to the change in the tax-credit policy. Moreover, the basic tax credit increased every year after its introduction, and yet the increases in employment stopped in 2000. In particular, the basic rate of WFTC at introduction was $£ 52.30$ per week and by 2003, when WFTC was replaced by the Working Tax Credit and Child Tax Credit, the rate stood at £62.50 per week. Several authors have acknowledged this trend, but while some have dismissed it as a temporary phenomenon which would not have continued after 1998 (Leigh (2007), Blundell et al. (2005)), others claim it was an "anticipation" effect (Francesconi and Van der Klaaw (2004)). However, there is little evidence (or financial gain) to suggest that single mothers would have benefited from entering into employment almost two years prior to the introduction of WFTC. We discuss this in more detail in Section 7.

Finally, because there were various tax and benefits reforms in the late 1990s that targeted single mothers, it is difficult to say if these policies had more or less impact than WFTC did on the employment rate of single mothers. Gregg and Harkness (2003) discuss the introduction of other policies directed at the low-skilled workers and/or families with children, which also impacted the employment rates of single mothers. Moreover, given the timing of these policies, it is not possible to disentangle the effects to see if the policies were jointly or separately significant. In particular, the two other relevant policies, which targeted the entry of low-skilled groups into the labor market, were 
the National Minimum Wage and the New Deal for Lone Parents. The National Minimum Wage was introduced in April 1999, six months prior to WFTC, to reduce the growing dispersion in wages in the UK (Dickens and Manning (2002)). The New Deal for Lone Parents, introduced in 1998, offered job-search assistance to single parents receiving of Income Support with children under $16 .{ }^{5}$

The main concern is that it is not clear that WFTC had the unambiguous effect of increasing employment among single mothers. In particular, we need to be sure that the methodology used can control for sure complexities. In the analysis that follows, we will concentrate on the heterogeneity in the effect on different parts of the hours distribution and the time-series changes in the employment of single mothers. However, trying to disentangle WFTC from other policies in the same period is difficult, if not impossible.

\subsection{The Control Group: Single Women without Children}

The evaluation problem is to identify the effect of WFTC on the employment of single mothers. The simple idea behind the differences-in-differences (DID) estimator is to measure the growth in the outcome variable of the treated compared with the non-treated. The estimator compares the pre-program period, $t_{0}$, and the post-program period, $t_{1}$ :

$$
\hat{\alpha}=\left(\bar{Y}_{t_{1}}^{T}-\bar{Y}_{t_{0}}^{T}\right)-\left(\bar{Y}_{t_{1}}^{C}-\bar{Y}_{t_{0}}^{C}\right)
$$

where $\bar{Y}^{T}$ and $\bar{Y}^{C}$ are the mean outcome for the treatment and control groups, respectively. However, an important assumption (relevant for our evaluation) that must hold is that the macro trends must have the same impact across the treatment and control groups. If there are differential impacts, it must be that the two groups have some characteristics that distinguish them and make them react differently to common macro shocks.

The control group must be as similar as possible to the treatment group in all dimensions other than that of eligibility. Most of the literature (Blundell et al (2005), Leigh (2007), Francesconi and Van der Klaaw (2007), Gregg and Harkness (2003)) uses people without children as a comparison

\footnotetext{
${ }^{5}$ The program allowed single parents to meet a personal advisor every two weeks and receive advice on job vacancies, in-work benefits, childcare arrangement, training and job search techniques.
} 
group when evaluating WFTC. In particular, the changing employment outcome of single mothers is compared with that of single, childless women. The assumption made, Eissa and Leibman (1996)point out, is that DID controls for any contemporaneous shocks to the labor-force participation of single women with children through the changes in participation for the control group.

Figure 3 shows that this comparison group violates the DID condition of having the same underlying trend in the pre-treatment period. We can see that, while the employment of single women without children is high and has remained steady, the employment rate of lone mothers has been steadily increasing. Table 1, which gives the descriptive statistics of these two groups in the period before the introduction of WFTC, reinforces this concern. One important distinction is that 22 percent of single women are highly qualified, compared with only six percent of single mothers, whereas only five percent of single women have no qualifications, compared with 13 percent of single mothers ${ }^{6}$.

One possibility may be that low-educated single childless women would be a better comparison group for single mothers. However, a close inspection of the movements in the employment rates of that group reveals that the trends are very similar to that of all single childless women. In Figures A1 and A2, we plot the employment rates for low-educated single childless women against single mothers and low-educated lone mothers, respectively, and find little similarity in pre-WFTC trends.

In the analysis that follows, we look more closely at the differential trends and, by close inspection of changes in covariates over time, at the sizable differentials (that are changing over time) in observable characteristics between the treatment and control groups.

\section{Data}

The empirical investigation is done using the UK's Quarterly Labour Force Survey (LFS). The LFS is a repeated cross-section quarterly survey that contains information on individuals, households and families. We use data from 1993 quarter 1 (March-May) to 2003 quarter 1 (March-May), inclusive. We do not go beyond this period since in mid-2003, WFTC was replaced by a different tax-credit policy. The dataset contains information on hours of work, labor market activity and a variety of control

\footnotetext{
${ }^{6}$ More description of the descriptive statistics is given in Section 4 .
} 
variables needed for the analysis-in particular, the region of residence; age; highest qualification; ethnicity; the presence of children; the number of children; and the age of the youngest child in the household. The sample is restricted to single women between 18 and 60 years old. Full-time students, the sick/disabled or individuals in a government training program are omitted from the sample. The resulting sample size, after pooling all 41 quarters, is approximately 366,500.

Table 1 presents the summary statistics for single women without children in the first column and for lone mothers in the second column. There are some clear differences between the two groups. Single mothers tend to be, on average, younger than single women without children (24.2 years versus 27.7 years), and they are more likely to be non-white (seven percent versus four percent). An important concern is that single mothers are less educated; a higher proportion have no qualifications (13 percent versus five percent), and a smaller proportion are highly qualified (six percent versus 22 percent). Another troubling distinction is the observable differences in the employment behavior of the two groups. Single mothers are likely to work, on average, 24.4 hours per week, while single childless women work, on average, 35.8 hours a week. Compared with single childless women, single mothers have a higher probability of being unemployed and inactive (ten percent versus 7.9 percent and 34.1 percent versus 8.5 percent, respectively). Overall, single mothers are less likely to be employed, 48.8 percent compared to 82.8 percent of single childless women. When looking at the hours distribution, single mothers have a higher probability of working part-time: 15.7 percent of single mothers work between 0-15 hours, compared with only nine percent of single childless women; and 11.4 percent of single mothers work 16-29 hours compared with only 7.2 percent of single childless women. Finally, only 22.3 percent of single mothers work more than 30 hours, compared with 66.7 percent of single childless women. 


\section{Evaluation I}

\subsection{Basic Analysis}

Following Eissa and Leibman (1996), we use a simple regression-based DID by estimating the following probit:

$$
\operatorname{Pr}\left(\text { emp }_{i t}=1\right)=\Phi\left(\beta_{0}+\mathbf{X}_{i t}^{\prime} \boldsymbol{\beta}_{1}+\beta_{2} t+\beta_{3} K I D_{i}+\beta_{4} \operatorname{Post}_{1999_{t}}+\gamma\left(K I D * \text { Post } 1999_{i t}\right)\right.
$$

where emp is a dummy equal to one if a woman reported working at least one hour. The vector of $\mathbf{X}$ characteristics includes the region of residence, age (and higher order age squared and age cubed), highest qualification, ethnicity, the presence of children, the number of children and the age of the youngest child in the household. We include a real deseasonalised GDP series, $t$, to control for the general economic conditions, and we also include seasonal controls. The time trend and the individual characteristics will control for the observable differences in the characteristics of the treatment and control groups that affect the level of employment. The $K I D$ variable simply denotes a dummy variable that is equal to one if the individual is a lone mother and zero otherwise. Unobservable differences are expected to be picked up here and we expect the coefficient, $\beta_{3}$, be be negative if single mothers have a lower employment rate than single childless women, even after controlling for children. $^{7}$ The Post1999 is a dummy equal to one for any quarter after Spring 2000. The coefficient, $\beta_{4}$, reflects the change in employment for both treatment and control groups post-WFTC introduction until Spring 2003. ${ }^{8}$ Finally, we construct a variable that will capture the treatment effect by interacting the post-WFTC, Post1999, variable with an indicator for the presence of children, KID. We are, therefore, implicitly testing that $\gamma$, the coefficient on the interaction term between Post1999 and $K I D$, is greater than zero. Our regression results in what follows are obtained from using data from the first quarter of 1993 to the first quarter of 2003.

\footnotetext{
${ }^{7}$ In the analysis, we disaggregate the "KID" variable by using the number of children. The omitted category is "no children" and we include the categories: 1 child, 2 children and 3 or more children.

${ }^{8}$ In April 2003, WFTC was replaced by the Working Tax Credit and Child Tax Credit.
} 
Table 2 presents the marginal effects of the above specifications. Column 1 shows the results for those aged 18 years and over, and column 2 presents the results for those aged 21 and over. We make this distinction to account for the possibility that many women may still be full-time students when under 21. The estimate of the treatment effect in column 1 suggests that WFTC raised employment by 3.6 percentage points. When looking at those over 21 , the result is stronger, at 4.2 percentage points. These results are significant at the one percent level and comply with the results in the literature, which average at five percentage points (see Brewer and Browne (2006)).

The other covariates in this regression strongly suggest that having children is an important factor in determining the probability of working. For example, having three or more children reduces the probability of working by 39 percent relative to those with no children. In addition, having children under the age of five reduces the probability of working by 22 percent. Finally, the probability of working monotonically falls as the level of qualifications falls, and non-whites are less likely to work.

However, the specification used here makes two very big assumptions. First, it assumes that the coefficient on the child dummy variable remains constant before the introduction of WFTC. Second, it assumes that the coefficients on other key covariates remain the same before and after the introduction of WFTC. In other words, we do not allow for any relative changes in the rates of return of covariates between single mothers and single women without children. In effect, a violation of these two assumptions would lead to the interaction term (between the child dummy variable and the post WFTC period) picking up the effect of these changes in the coefficients and would bias our estimates of treatment effect.

In the following analysis, we look carefully at both of these possibilities. In addition, we look closely to see who is affected by the policy change. More specifically, we look to see where along the hours distribution the strongest impact of WFTC lies. We also look at the impact of WFTC on different labor-market states to see if single mothers are being drawn from inactivity and/or if they are increasing overall participation (with increases in unemployment). 


\subsection{Controlling for Differential Trends}

In Section 3.1, we looked at the time-series movements in the employment rates of single mothers relative to single childless women and it was clear that there were differential trends in employment rates. The traditional DID analysis fails to allow for these differences. Therefore, we extend our DID analysis to allow for the possibility of differential trends between women with children and those without children:

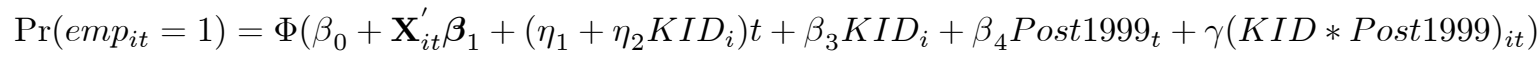

We allow for differential trends between our control and treatment groups by interacting the KID with the time trend, $t$. It can be seen that without controlling for this difference, the treatment effect would be biased upwards:

$$
E[\gamma \mid X, .]=\gamma+\eta_{2}\left(k+k^{\prime}\right)>\gamma
$$

where $\left(k+k^{\prime}\right)$ represents the average number of periods between the post-WFTC and pre-WFTC period observations.

The results presented in Table 3 show that once we control for differential trends for women with children and women without children, the impact of WFTC on employment falls to 1.7-1.8 percentage points. All other covariates give a quantitatively similar picture as Table 2, when we do not include the differential trend.

These results suggest that the effectiveness of WFTC seen in the previous section has been exaggerated. A large part of the increase in employment of single mothers estimated (4.2 percentage points), reflects the changing trend in their attachment to the labor market. In Section 6, we look more closely at the effect of the presence of children on employment over the period 1993 to 2003. 


\subsection{Hours Distribution Effect}

Another important concern relates to our understanding of which part of the hours distribution was affected by the introduction of WFTC. Given that there was a 16-hour minimum work requirement for WFTC, one would expect the impact of WFTC to be the greatest on those working at least 16 hours. In this section, we examine at the probability of working fewer than 16 hours (0-15 hours), of working part-time (16-29 hours), and of working full-time (30 hours or more).

We run the same specification as we did for employment in Section 5.2 and report the results in Table 4. The first column of each group of hours reports the results without controls for differential trends. As one might expect, there are no significant effects on those working fewer than 16 hours (the hours threshold); there is an increase of 3.8 percentage points in the probability of working between 16 and 29 hours and an increase of 1.8 percentage points in the probability of working more than 30 hours.

When we control for the differential trends, the only treatment effect that remains significant is on those working more than 30 hours. We find an effect of 1.3 percentage points on working full-time, at the ten percent significance level. This is a very interesting result, as it is consistent with the predictions laid out in Section 3.1, which reported that the net income increase from WFTC was small below 25 hours of work due to interactions of WFTC with other taxes and benefits.

These results question whether the policy was designed well. Given that the policy targeted those with no labor-market attachment, one would expect this group to be more attracted to working parttime. In addition, one might expect that those we observe working 30 hours were probably those in work before the introduction of WFTC and may have simply increased their number of hours of work. Although this does not imply that the policy was unsuccessful, it does seem to suggest that the policy did not affect the main target group-i.e., those with little attachment to the labor market. In the next section, we look to see whether WFTC increased employment by those previously inactive. 


\section{Evaluation II}

\subsection{Changes in Coefficients over time}

The results from the previous section raise questions relating to how the child (treatment) coefficient changed between1993 and 2003. In conjunction with this, it is also important to look more closely at the movements of the other (relative) covariates over the same time period. By doing so we can increase our insight into exactly how the introduction of WFTC affected employment.

\subsubsection{Child Coefficient}

To observe how the relative employment probabilities for those with children versus no children changed between 1993 and 2003, we estimate the following equation for each year:

$$
\operatorname{Pr}\left(e m p_{i t}=1\right)=\Phi\left(\beta_{0 t}+\mathbf{X}_{i t}^{\prime} \boldsymbol{\beta}_{1 t}+\beta_{3 t} K I D_{i t}\right)
$$

The movements in the coefficient on the presence of children over the period 1993-2003, reported in Table 5, show a closing gap between women with children and those without children. This is shown very clearly in Figure 9, which plots the coefficient. The initial gap in employment probability between single mothers and single women without children is -36 percent. The coefficient starts falling in 1994 and then, after a small a blip in 1998, it continues to fall to -0.27 . One may argue that this reflects an anticipated WFTC effect. However, there is no reason to believe that almost two years before the introduction, people would have reacted to the policy as it would mean giving up a number of entitled benefits. Another pressing concern is that there were increase in WFTC in 2001 and 2002, above the rate of inflation, and yet the child coefficient flattened in 2000. We discuss these issues in more detail in Section 7 .

\subsubsection{Other Covariates}

To look at the changes in other important covariates, we estimate the following: 


$$
\operatorname{Pr}\left(e m p_{i t}=1\right)=\Phi\left(\beta_{0 t}+\mathbf{X}_{i t}^{\prime} \boldsymbol{\beta}_{1 t}+\beta_{3 t} K I D_{i t}+\delta_{t}(K I D * \mathbf{X})_{i t}\right)
$$

In Figures 10 to 12 (and Tables A2 to A4), we look at the effect of the age of children, the number of children and the relative returns to education between single mothers and other single women, respectively. First, in Figure 10, when looking at the different ages of children, we find that the biggest increases are for those with children aged zero to five years. Although, there was continuous growth over the ten years, the biggest increase occurred between 1998 and 2000,but then stagnated. Again, it is surprising that the impact occurred before the introduction of WFTC.

In Figure 11, we look at the effect of the number of children on employment. The coefficient of having one, two or three (or more) children seems to be increasing over time. The largest spike, however, came from those with only one or two children. This may due to the fact that both WFTC and its predecessor, Family Credit, offer only small supplements per extra child in the household, reducing the incentive to work. This is true, in particular, if there are two or more children in the household under the age of five.

Finally, in Figure 12, we look at the changes in the relative returns to qualifications/education for single mothers versus other single women. By holding the highest-educated as the control group, there seems to have been some (relative) change between the different education group-in particular, between low-educated women with and without children-the gap seems to be closing from 1995/6.

\subsection{Hours of Work}

Another interesting question is: what happened to the hours distribution before and after the introduction of WFTC? Figures 5a, 5b and 5c show the average fraction of people working 0-15 hours, 16-29 hours and 30 hours or more, respectively. It is clear that, while the distributions remained constant from 1993 to 2003 for single childless women, fewer single mothers are working fewer than 16 hours, and there has been a significant increase in those working between 16 and 29 hours. These changes, however, do not appear significant in our analysis of WFTC because the increase has been continuous since 1993 and there was no noticeable spike in October 1999. The average number of 
single mothers working 30 hours or more has remained fairly constant since 1996, with only slight increases during the WFTC introduction period. This corresponds with the small increases we observe in the regression results.

Changes in Coefficients When we look at the change in the child coefficient for each group of hours (0-15 hours, 16-29 hours and 30 or more hours), the patterns correspond well to the patterns seen in Figures 5a-5c. In particular, looking at Figure 13a, we see that, although the relative effect of working 0-15 hours was higher for single mothers than for single childless women, the coefficient fell after 1995 and again after 2000. Figure 13b shows that effect of being a lone mother on working between 16 and 29 hours is always relatively higher than for single childless women; however, this was a continuously growing pattern, with no acceleration in October 1999. Finally, Figure 13c looks at the change in the child dummy on working more than 30 hours. Here the pattern seems quite similar to the overall employment pattern in Figure 10. We can see that, although single childless women are always more likely to work full-time, the relative difference (after 1995) fell and, after 1998, the gap closed significantly. However, after 2001, the gap began to widen again. If the increase in the probability that single mothers would work more than 30 hours was due to WFTC, one may question its long-term effectiveness.

\subsection{Labor-Market States}

In Table 6 we look at the effect of WFTC on entering other labor-market states. The results imply that when we control for trends, the probability of entering unemployment falls 1.7 percentage points. One may interpret this result in many ways. On the one hand, we would expect WFTC to have increased all labor-market participation. Thus, it would increase not only employment, but, given labor-market friction, also job search. On the other hand, we may expect unemployment to have fallen because people were accepting job offers less reluctantly and/or searching with more intensity for a job.

When looking at the effect of WFTC on inactivity, there seemed to be no significant effect. This is very interesting, as it suggests that women who entered the workforce did not come from inactivity 
but from unemployment, or that they were already employed and now simply increasing the number of hours worked.

Changes in Coefficients Further analysis in Figures 14a and 14b, which look at the time series movement of the child coefficient for those unemployed and inactive, respectively, suggests that unemployment of single mothers, relative to single childless women, increased substantively since 1993, then fell between 1998 to 2000, and later increased again after 2001. This is analogous to the employment story and suggests that female participation increased throughout the 1990s. The dip in 1998 may be explained by other labor-market policies introduced, such as the New Deal for Lone Parents, which assisted lone mothers to search more effectively for jobs and required that their welfare receipt became contingent on the search.

Figure 14b, which plots the time series changes in the child coefficient, implies that inactivity rates of single mothers relative to single childless women fell consistently during the 1990s, but by 2000 , the rate remained constant, at 25 percent.

\section{$7 \quad$ Why did the Child Coefficient Increase?}

We have shown that over the period 1993 to 1999, before the introduction of WFTC, the employment rate of single mothers increased by 7.8 percent and that the relative employment probability of single mothers to single childless women, ceteris paribus, increased from -0.38 to -0.27 over the same period. It is important to understand why we observe this increasing trend and to ask if this trend would have continued in the absence of WFTC.

By 1992, the number of single mothers had increased fivefold since the 1970s, to just under 500,000. However, some of this increase related to changes in attitude. For example, in 1971, a third of couples who conceived outside marriage then had a "shot-gun" wedding, whereas in 1991, fewer than one in ten did so. Moreover, for teenagers who conceived outside marriage, almost one half married in 1971 compared with only one in 20 in 1991 (see Burghes (1995)). Other changes included that there were fewer single mothers in their teens in the 1990s than in the 1980s. Overall, compositional changes and 
changes in attitudes towards single mothers may explain some of the observed changes in employment.

One argument proposed to explain the increasing trend in employment rates for single mothers was that WFTC was anticipated. In its March 1998 Budget speech, the New Labour Government announced the introduction of WFTC and other reforms targeted to "make work pay" for low-income families with children. However, there are three important reasons to question the plausibility that single mothers would react to this announcement, which came almost two years prior to the actual policy change. First, we observe increases in employment for single mothers before 1998. Secondly, there were smaller financial incentives (and, most likely, income losses) to enter the labor market before the introduction of WFTC. Finally, there were other policy changes between 1998 and 1999 that affected lone mothers. We will discuss each separately.

First, there have been a huge number of polices over the last two decades intended to attract single mothers and, more generally, women and/or the low-skilled, into employment. These ranged from the introduction of the Equal Pay Legislation in 1970 to the increased flexibility in the labor market, which promoted part-time work. In addition, the improved nature and quality of childcare also promoted work among this group of women. Moreover, the 1994 change to Family Credit, which made it more generous and introduced a bonus amount for working 30 hours or more, also increased participation (See Duncan (1996)). All of these changes took place before 1998.

A report published by Nobles et al. (1998) looks at the period 1993 to 1997 and shows that there was an increase in the number of single parents moving from Income Support, due in part, to changes in Family Credit. They observed that of the single mothers on Income Support in July 1993, only 20 percent remained on Income Support for the whole period. In particular, young single mothers (aged 25 or under) were most likely to come off Income Support, and they tended to be better qualified. In their qualitative analysis, the authors observed a positive orientation towards work among single mothers and discovered that most women had worked (at least for some time) since they first had children. The main reasons given for not working were related to childcare (because of the marginal nature of the work they undertook: short-term, low-paid, with unsocial hours) and the loss of benefits, neither of which was addressed until after WFTC was introduced. 
Second, the interactions between Housing Benefit, Income Support and Child Support (as well as Income Tax and National Insurance Contribution) imply that single mothers, not previously in the labour market, would have incurred a great deal of additional costs to enter the labor market with the anticipation of future payment. In particular, Blundell and Walker (2001) show that although in-work benefits (before WFTC) provided some financial incentives to work, the combined effect of the 55 percent reduction rate, together with the impact of the Housing Benefit, the personal tax rates and National Insurance Contributions in the UK resulted in implicit tax rates close to 100 percent. The WFTC strengthened incentives by increasing the generosity and the reduction rate. It also incorporated a new childcare credit of 70 percent of eligible childcare costs up to a limit of $£ 100$ (and $£ 150$ for two children). None of these additional benefits was available until after October 1999.

It is important to point out that, although WFTC was more active towards "making work pay," the interactions with other benefits, which strongly offset the effectiveness of the increased generosity of WFTC, meant that most of the gain were concentrated in the middle or top of the hours distribution for single-parent households. For example, the Housing Benefit is computed after WFTC, and so WFTC is counted as income in determining the Housing Benefit entitlement, and hence, overall income. The results in this paper highlight this effect.

Third, the introduction of the New Deal for Lone Parents in 1998 and the National Minimum Wage in 1999, which targeted low-income people and, in particular, families with children, implies that they played an important role in increasing employment amongst this group in the pre-WFTC period. Thus, it was not the anticipation of WFTC that increased employment after 1998, but a reaction to the range of policies, that existed around that time. It is of critical importance to encapsulate these policies into the analysis to avoid overestimating the true effect of WFTC. With the exception of Gregg and Harkness (2003), the literature discounts the importance of these policies and attribute any post-1998 increase in employment to WFTC.

Finally, it is important to question whether the increase in employment observed before October 1999 would have continued in the absence of WFTC. Given the interaction of different policy introductions, the effect of WFTC is not easy to disentangle, making this a tough question to answer. There 
were, however, increases in the generosity of WFTC between 2000 and 2002 and changes in income tax and National Insurance rules (such that a ten percent income tax band was introduced and the two percent National Insurance entry fee was abolished), which meant that there should have been improved incentives for part-time workers and low-earning workers. However, we observe that over that period, employment for single mothers flattened and the child coefficient was stable. This may be because WFTC lacked effectiveness, or it may be that the effects were dampened by the increase in Income Support over the same period and the loss of the Housing Benefit.

Overall, although WFTC and even, perhaps, its anticipation seems to have had some effect on the employment of single mothers, the effects have been exaggerated because the lack of attention given to other policies of the 1990s and, perhaps, differential contemporaneous shocks between people with and without children. In addition, we are interested not only in whether WFTC increased employment, but also in whether the government succeeded in increasing the participation and hours of work of their target group. By looking at the changes in the hours distribution and the labor-market states, it is not clear that those with the least labor-market attachment were encouraged into the labor market.

\section{Conclusion}

The increased use of tax credits as a method of "in work benefits" has raised a great deal of popular interest in the UK and in many other countries where they have been initiated. In particular, the success of the program was said to lie mainly in the increase in the employment of single parents. This paper looks closely at the effectiveness of WFTC in increasing employment, hours of work and movements from different labor-market states. The evidence suggests that once we control for the differential trends in employment between lone mothers and single childless women, who are used as the control group, the employment effect from WFTC fell considerably. This is confirmed when we look at the movements of the coefficients over time. Moreover, we find that the policy did not induce people from outside of the labor market (i.e. from inactivity)-the main target group. Instead, we find that any effect of WFTC is borne solely by those working 30 hours or more. 


\section{References}

[1] Azmat, G. Y., 2006. The Impact of Tax Credits on Labour Supply. UPF Working Paper, Paper No: WP979

[2] Blundell, R., Brewer, M., Shephard, A., 2005. Evaluating the Labour Market Impact of Working Families' Tax Credit using difference-in-differences. HM Revenue and Customs.

[3] Blundell, R., Duncan, D., McCrae. J., Meghir, C., 2000. The Labour Market Impact of the Working Families' Tax Credit. Fiscal Studies, vol. 21, no. 1, pp. 75-104.

[4] Blundell, R., Walker, I., 2001. Working Families' Tax Credit: A Review of the Evidence, Issues and Prospects for Future Research. Inland Revenue.

[5] Brewer, M., Browne, J., 2006. The Effect of the Working Families' Tax Credit on Labour Market Participation. IFS Briefing Note No. 69.

[6] Brewer, M., Duncan, A., Shephard, A., Jose-Suarez, M., 2005. Did Working Families' Tax Credit work? The final evaluation of the impact of in-work support on parent' labour supply and take-up behaviour in the UK. HM Revenue and Customs.

[7] Brewer, M., Clark, T., Wakefield, M., 2002. Five Years of Social Security Reforms in the UK. Institute for Fiscal Studies, Working Paper W02/12.

[8] Burghes, L. with Brown, M., Singles Lone Mothers: Problems, Prospects and Policies. Family \& Parenthood Series. Family Policy Studies Centre.

[9] Dickens, R., Manning, A., 2002. Has the National Minimum Wage Reduced UK Wage Inequality?. LSE, Centre for Economic Performance Working Paper No. 533.

[10] Duncan, A., Giles, C., 1996. Labour Supply Incentives and Recent Family Credit Reforms. The Economic Journal, vol 106, No. 434, 142-155.

[11] Eissa, N., Leibman, J. B., 1996. Labour Supply Response to the Earned Income Tax Credit. The Quarterly Journal of Economics, vol 111, 605-637. 
[12] Francesconi, M., Van der Klaaw, W., 2004. The Consequences of 'In-Work' Benefit Reform in Britain: New Evidence from panel Data. IZA Discussion Paper No. 1248

[13] Francesconi, M., Van der Klaaw, W., 2007. Socioeconomic Consequences of 'In-Work' Benefit Reform for British Lone Mothers. Journal of Human Resources, vol. 42 (1), pp. 1-31

[14] Goodman, A., 2001. Inequality and Standards of Living in Great Britain: Some Facts. Institute for Fiscal Studies Briefing Note No. 19.

[15] Gregg, P., Harkness, S., 2003. Welfare Reform and Lone Parents in the UK. CMPO Working Paper Series No. 03/072.

[16] Inland Revenue. Working Families' Tax Credit \& Family Credit Statistics. Quarterly Enquiry, November 1999.

[17] Leigh, A., 2007. Earned Income Tax Credits and Labour Supply: New Evidence from a British Natural Experiment. National Tax Journal, vol. LX, No. 2.

[18] McKnight, A., 2005. Employment: Tackling Poverty Through 'Work For Those Who Can'. In Hills, J., Stewart, K. (Eds),A More Equal Society, Centre for Analysis of Social Exclusion (CASE), London School of Economics

[19] Nobles, M., Smith, G., Cheung, S.Y., 1998. Lone Mothers Moving In and Out of Benefits. Published by YPS for the Joseth Rowntree Foundation. 
TABLE 1: Descriptive Statistics - Before WFTC

\begin{tabular}{|c|c|c|}
\hline Variable & Single Childless Women & Single Mothers \\
\hline Age & $\begin{array}{r}27.065 \\
{[8.881]} \\
\end{array}$ & $\begin{array}{c}23.928 \\
{[7.541]} \\
\end{array}$ \\
\hline White & $\begin{array}{c}0.956 \\
{[0.205]} \\
\end{array}$ & $\begin{array}{c}0.922 \\
{[0.267]} \\
\end{array}$ \\
\hline Black & $\begin{array}{c}0.021 \\
{[0.142]} \\
\end{array}$ & $\begin{array}{c}0.048 \\
{[0.214]}\end{array}$ \\
\hline Asian & $\begin{array}{c}0.018 \\
{[0.135]} \\
\end{array}$ & $\begin{array}{c}0.024 \\
{[0.153]} \\
\end{array}$ \\
\hline Other Ethnicity & $\begin{array}{c}0.005 \\
{[0.071]} \\
\end{array}$ & $\begin{array}{c}0.005 \\
{[0.073]} \\
\end{array}$ \\
\hline High Qualifications & $\begin{array}{c}0.195 \\
{[0.396]} \\
\end{array}$ & $\begin{array}{r}0.055 \\
{[0.227} \\
\end{array}$ \\
\hline Medium Qualification & $\begin{array}{c}0.375 \\
{[0.484]} \\
\end{array}$ & $\begin{array}{c}0.300 \\
{[0.458]} \\
\end{array}$ \\
\hline Low Qualifications & $\begin{array}{c}0.363 \\
{[0.481]} \\
\end{array}$ & $\begin{array}{c}0.516 \\
{[0.500]} \\
\end{array}$ \\
\hline No Qualifications & $\begin{array}{c}0.067 \\
{[0.251]} \\
\end{array}$ & $\begin{array}{c}0.130 \\
{[0.336]} \\
\end{array}$ \\
\hline Hours of Work & $\begin{array}{c}34.926 \\
{[12.600]} \\
\end{array}$ & $\begin{array}{c}25.167 \\
{[14.475]} \\
\end{array}$ \\
\hline Work 0-15 Hours & $\begin{array}{c}0.090 \\
{[0.286]} \\
\end{array}$ & $\begin{array}{c}0.157 \\
{[0.363]} \\
\end{array}$ \\
\hline Work 16-29 Hours & $\begin{array}{c}0.072 \\
{[0.258]} \\
\end{array}$ & $\begin{array}{c}0.114 \\
{[0.317]} \\
\end{array}$ \\
\hline Work 30+ Hours & $\begin{array}{c}0.668 \\
{[0.471]} \\
\end{array}$ & $\begin{array}{c}0.223 \\
{[0.416]} \\
\end{array}$ \\
\hline Employed & $\begin{array}{c}0.828 \\
{[0.378]} \\
\end{array}$ & $\begin{array}{c}0.488 \\
{[0.500]} \\
\end{array}$ \\
\hline Unemployed & $\begin{array}{c}0.079 \\
{[0.269]} \\
\end{array}$ & $\begin{array}{c}0.101 \\
{[0.301]} \\
\end{array}$ \\
\hline Inactive & $\begin{array}{c}0.085 \\
{[0.278]} \\
\end{array}$ & $\begin{array}{c}0.341 \\
{[0.474]} \\
\end{array}$ \\
\hline One Child & & $\begin{array}{c}0.712 \\
{[0.453]}\end{array}$ \\
\hline
\end{tabular}




\begin{tabular}{|c|c|c|}
\hline Two Children & & $\begin{array}{c}0.221 \\
{[0.415]}\end{array}$ \\
\hline Three or More Children & & 0.068 \\
& & {$[0.251]$} \\
\hline Youngest Child (0 to 5 years) & & 0.377 \\
& & {$[0.485]$} \\
\hline Youngest Child (6 to 11 years) & & 0.301 \\
& & {$[0.459]$} \\
\hline Youngest Child (12 to 16 years) & & 0.314 \\
& & {$[0.464]$} \\
\hline Observations* & $\mathbf{1 6 3 8 1 2}$ & $\mathbf{4 9 9 0 7}$ \\
\hline
\end{tabular}

NOTES: Data from the UK Quarterly Labour Force Survey (1993-1998). Here, we see the means and standard deviations in brackets for each group. The sample includes individuals aged 18-60. The sample is restricted to working women. 
TABLE 2: Employment - Basic Regression Results (1993-2003)*

\begin{tabular}{|c|c|c|}
\hline & 18 years + & 21 years + \\
\hline Treatment Effect & $\mathbf{0 . 0 3 6}$ & $\mathbf{0 . 0 4 6}$ \\
Age & {$[\mathbf{0 . 0 0 3}]^{* *}$} & {$[\mathbf{0 . 0 0 3}]^{* *}$} \\
& 0.045 & 0.06 \\
One Child & {$[0.003]^{* *}$} & {$[0.004]^{* *}$} \\
& -0.075 & -0.145 \\
Two Children & {$[0.004]^{* *}$} & {$[0.006]^{* *}$} \\
& -0.154 & -0.252 \\
3 or more Children & {$[0.006]^{* *}$} & {$[0.008]^{* *}$} \\
& -0.26 & -0.389 \\
Medium Qual & {$[0.008]^{* *}$} & {$[0.009]^{* *}$} \\
& -0.035 & -0.043 \\
Low Qual & {$[0.003]^{* *}$} & {$[0.003]^{* *}$} \\
& -0.131 & -0.141 \\
No Qual & {$[0.003]^{* *}$} & {$[0.003]^{* *}$} \\
& -0.432 & -0.434 \\
Youngest Child 0-5 & {$[0.003]^{* *}$} & {$[0.004]^{* *}$} \\
& -0.319 & -0.223 \\
Youngest Child 6-11 & {$[0.005]^{* *}$} & {$[0.006]^{* *}$} \\
& -0.103 & -0.07 \\
Black & {$[0.005]^{* *}$} & {$[0.006]^{* *}$} \\
Asian & -0.078 & -0.062 \\
Trend & {$[0.005]^{* *}$} & {$[0.005]^{* *}$} \\
Other Ethnicity & -0.111 & -0.121 \\
& {$[0.006]^{* *}$} & {$[0.007]^{* *}$} \\
& -0.11 & -0.106 \\
& {$[0.009]^{* *}$} & {$[0.010]^{* *}$} \\
& 0.006 & 0.008 \\
& {$[0.000]^{* *}$} & {$[0.000]^{* *}$} \\
& -0.026 & -0.036 \\
& {$[0.003]^{* *}$} & {$[0.003]^{* *}$} \\
\hline & 367699 & $\mathbf{2 9 7 9 0 8}$ \\
\hline
\end{tabular}

NOTES: We also control for region of residence, age squared and age cubed. The omitted comparison categories are: No Children, High Qualification, Youngest Child 12-16, White. The coefficients and standard errors (in brackets) are reported. ** represents significance at the $1 \%$ level, * represents significance at the $5 \%$ level and ${ }^{+}$represents significance at the $10 \%$ level. 
TABLE 3: Employment - Differential Trend Control Regression Results (1993-2003)

\begin{tabular}{|c|c|c|c|c|}
\hline & \multicolumn{2}{|c|}{18 years +} & \multicolumn{2}{|c|}{21 years +} \\
\hline & No Trend & Trend & No Trend & Trend \\
\hline \multirow[t]{2}{*}{ Treatment Effect } & 0.036 & 0.018 & 0.046 & 0.017 \\
\hline & {$[0.003]^{* *}$} & {$[0.005]^{* *}$} & {$[0.003]^{* *}$} & {$[0.006]^{* *}$} \\
\hline \multirow[t]{2}{*}{ Age } & 0.045 & 0.045 & 0.06 & 0.06 \\
\hline & {$[0.003]^{* *}$} & {$[0.003]^{* *}$} & {$[0.004]^{* *}$} & {$[0.004]^{* *}$} \\
\hline \multirow[t]{2}{*}{ One Child } & -0.075 & -0.09 & -0.145 & -0.172 \\
\hline & {$[0.004]^{* *}$} & {$[0.006]^{* *}$} & {$[0.006]^{* *}$} & {$[0.007]^{* *}$} \\
\hline \multirow[t]{2}{*}{ Two Children } & -0.154 & -0.171 & -0.252 & -0.283 \\
\hline & {$[0.006]^{* *}$} & {$[0.007]^{* *}$} & {$[0.008]^{* *}$} & {$[0.009]^{* *}$} \\
\hline \multirow[t]{2}{*}{3 or more Children } & -0.26 & -0.278 & -0.389 & -0.419 \\
\hline & {$[0.008]^{* *}$} & {$[0.008]^{* *}$} & {$[0.009]^{* *}$} & {$[0.009] * *$} \\
\hline \multirow[t]{2}{*}{ Medium Qual } & -0.035 & -0.035 & -0.043 & -0.044 \\
\hline & {$[0.003]^{* *}$} & {$[0.003]^{* *}$} & {$[0.003]^{* *}$} & {$[0.003]^{* *}$} \\
\hline \multirow[t]{2}{*}{ Low Qual } & -0.131 & -0.131 & -0.141 & -0.141 \\
\hline & {$[0.003]^{* *}$} & {$[0.003]^{* *}$} & {$[0.003]^{* *}$} & {$[0.003]^{* *}$} \\
\hline \multirow[t]{2}{*}{ No Qual } & -0.432 & -0.432 & -0.434 & -0.434 \\
\hline & {$[0.003]^{* *}$} & {$[0.003]^{* *}$} & {$[0.004]^{* *}$} & {$[0.004]^{* *}$} \\
\hline \multirow[t]{2}{*}{ Youngest Child 0-5 } & -0.319 & -0.32 & -0.223 & -0.223 \\
\hline & {$[0.005]^{* *}$} & {$[0.005]^{* *}$} & {$[0.006]^{* *}$} & {$[0.006]^{* *}$} \\
\hline \multirow[t]{2}{*}{ Youngest Child 6-11 } & -0.103 & -0.104 & -0.07 & -0.07 \\
\hline & {$[0.005]^{* *}$} & {$[0.005]^{* *}$} & {$[0.006]^{* *}$} & {$[0.006]^{* *}$} \\
\hline \multirow[t]{2}{*}{ Black } & -0.078 & -0.078 & -0.062 & -0.061 \\
\hline & {$[0.005]^{* *}$} & {$[0.005]^{* *}$} & {$[0.005]^{* *}$} & {$[0.005]^{* *}$} \\
\hline \multirow[t]{2}{*}{ Asian } & -0.111 & -0.111 & -0.121 & -0.121 \\
\hline & {$[0.006]^{* *}$} & {$[0.006]^{* *}$} & {$[0.007]^{* *}$} & {$[0.007]^{* *}$} \\
\hline \multirow[t]{2}{*}{ Other Ethnicity } & -0.11 & -0.111 & -0.106 & -0.106 \\
\hline & {$[0.009]^{* *}$} & {$[0.009]^{* *}$} & {$[0.010]^{* *}$} & {$[0.010]^{* *}$} \\
\hline \multirow[t]{2}{*}{ Trend } & 0.006 & 0.005 & 0.008 & 0.005 \\
\hline & {$[0.000]^{* *}$} & {$[0.001]^{* *}$} & {$[0.000]^{* *}$} & {$[0.001]^{* *}$} \\
\hline Post 2000 & -0.026 & -0.019 & -0.036 & -0.023 \\
\hline & {$[0.003]^{* *}$} & {$[0.004]^{* *}$} & {$[0.003]^{* *}$} & {$[0.004] * *$} \\
\hline \multirow[t]{2}{*}{ Trend_Child } & & 0.004 & & 0.007 \\
\hline & & {$[0.001]^{* *}$} & & {$[0.001]^{* *}$} \\
\hline Observations & 367699 & 367699 & 297908 & 297908 \\
\hline
\end{tabular}

NOTES: We also control for region of residence, age squared and age cubed. The omitted comparison categories are: No Children, High Qualification, Youngest Child 12-16, White. The coefficients and standard errors (in brackets) are reported. ** represents significance at the $1 \%$ level, * represents significance at the $5 \%$ level and ${ }^{+}$represents significance at the $10 \%$ level. 
TABLE 4: Hours Distribution Regression Results (1993-2003)

\begin{tabular}{|c|c|c|c|c|c|c|}
\hline \multirow{4}{*}{ Treatment Effect } & \multicolumn{2}{|c|}{ Work 0-15 Hours } & \multicolumn{2}{|c|}{ Work 16-29 Hours } & \multicolumn{2}{|c|}{ Work 30+ Hours } \\
\hline & No Trend & Trend & No Trend & Trend & No Trend & Trend \\
\hline & 0.002 & -0.002 & 0.038 & -0.001 & 0.018 & 0.013 \\
\hline & {$[0.002]$} & {$[0.002]$} & {$[0.003]^{* *}$} & {$[0.004]$} & {$[0.005]^{* *}$} & {$[0.008]+$} \\
\hline \multirow[t]{2}{*}{ Age } & -0.014 & -0.014 & -0.007 & -0.008 & 0.088 & 0.088 \\
\hline & {$[0.002]^{* *}$} & {$[0.002]^{* *}$} & {$[0.003]^{* *}$} & {$[0.003]^{* *}$} & {$[0.005]^{* *}$} & {$[0.005]^{* *}$} \\
\hline \multirow[t]{2}{*}{ One Child } & 0.044 & 0.041 & 0.078 & 0.043 & -0.245 & -0.249 \\
\hline & {$[0.003]^{* *}$} & {$[0.004]^{* *}$} & {$[0.004]^{* *}$} & {$[0.005]^{* *}$} & {$[0.006]^{* *}$} & {$[0.008]^{* *}$} \\
\hline \multirow[t]{2}{*}{ Two Children } & 0.064 & 0.059 & 0.066 & 0.03 & -0.393 & -0.396 \\
\hline & {$[0.005]^{* *}$} & {$[0.005]^{* *}$} & {$[0.005]^{* *}$} & {$[0.005]^{* *}$} & {$[0.006]^{* *}$} & {$[0.007]^{* *}$} \\
\hline \multirow[t]{2}{*}{3 or more Children } & 0.04 & 0.036 & 0.01 & -0.017 & -0.462 & -0.464 \\
\hline & {$[0.005]^{* *}$} & {$[0.005]^{* *}$} & {$[0.004]^{*}$} & {$[0.004]^{* *}$} & {$[0.006]^{* *}$} & {$[0.007]^{* *}$} \\
\hline \multirow[t]{2}{*}{ Medium Qual } & 0.003 & 0.003 & -0.006 & -0.006 & -0.025 & -0.025 \\
\hline & {$[0.001]^{*}$} & {$[0.001]^{*}$} & {$[0.001]^{* *}$} & {$[0.001]^{* *}$} & {$[0.003]^{* *}$} & {$[0.003]^{* *}$} \\
\hline \multirow[t]{2}{*}{ Low Qual } & 0 & 0 & -0.01 & -0.01 & -0.116 & -0.116 \\
\hline & {$[0.001]$} & {$[0.001]$} & {$[0.001]^{* *}$} & {$[0.001]^{* *}$} & {$[0.003]^{* *}$} & {$[0.003]^{* *}$} \\
\hline \multirow[t]{2}{*}{ No Qual } & -0.01 & -0.01 & -0.035 & -0.035 & -0.397 & -0.397 \\
\hline & {$[0.001]^{* *}$} & {$[0.001]^{* *}$} & {$[0.001]^{* *}$} & {$[0.001]^{* *}$} & {$[0.003]^{* *}$} & {$[0.003]^{* *}$} \\
\hline \multirow[t]{2}{*}{ Youngest Child 0-5 } & 0.013 & 0.013 & 0.032 & 0.032 & -0.33 & -0.33 \\
\hline & {$[0.003]^{* *}$} & {$[0.003]^{* *}$} & {$[0.004]^{* *}$} & {$[0.004]^{* *}$} & {$[0.006]^{* *}$} & {$[0.006]^{* *}$} \\
\hline \multirow[t]{2}{*}{ Youngest Child 6-11 } & 0.024 & 0.024 & 0.048 & 0.048 & -0.167 & -0.167 \\
\hline & {$[0.003]^{* *}$} & {$[0.003]^{* *}$} & {$[0.004]^{* *}$} & {$[0.004]^{* *}$} & {$[0.007]^{* *}$} & {$[0.007]^{* *}$} \\
\hline \multirow[t]{2}{*}{ Black } & -0.006 & -0.006 & 0.006 & 0.007 & -0.057 & -0.057 \\
\hline & {$[0.002]^{* *}$} & {$[0.002]^{* *}$} & {$[0.003]^{*}$} & {$[0.003]^{*}$} & {$[0.005]^{* *}$} & {$[0.005]^{* *}$} \\
\hline \multirow[t]{2}{*}{ Asian } & 0.017 & 0.017 & 0.001 & 0.001 & -0.129 & -0.129 \\
\hline & {$[0.003]^{* *}$} & {$[0.003]^{* *}$} & {$[0.004]$} & [0.004] & {$[0.007]^{* *}$} & {$[0.007]^{* *}$} \\
\hline \multirow[t]{2}{*}{ Other Ethnicity } & 0 & 0 & 0.001 & 0.001 & -0.106 & -0.106 \\
\hline & [0.004] & [0.004] & {$[0.006]$} & {$[0.006]$} & {$[0.011]^{* *}$} & {$[0.011]^{* *}$} \\
\hline \multirow[t]{2}{*}{ Trend } & 0.001 & 0 & 0.005 & 0.002 & 0.002 & 0.002 \\
\hline & {$[0.000]^{* *}$} & {$[0.000]$} & {$[0.000]^{* *}$} & {$[0.000]^{* *}$} & {$[0.001]^{* *}$} & {$[0.001]^{* *}$} \\
\hline \multirow[t]{2}{*}{ Post 2000} & -0.006 & -0.004 & -0.017 & -0.003 & -0.012 & -0.011 \\
\hline & {$[0.001]^{* *}$} & {$[0.002]^{* *}$} & {$[0.002]^{* *}$} & [0.002] & {$[0.004]^{* *}$} & {$[0.004]^{*}$} \\
\hline \multirow[t]{2}{*}{ Trend_Child } & & 0.001 & & 0.007 & & 0.001 \\
\hline & & [0.000] & & {$[0.001]^{* *}$} & & {$[0.001]$} \\
\hline Observations & 293868 & 293868 & 292088 & 292088 & 297969 & 297969 \\
\hline
\end{tabular}

NOTES: We also control for region of residence, age squared and age cubed. The omitted comparison categories are: No Children, High Qualification, Youngest Child 12-16, White. Analysis restricted to those aged 21 years and older. The coefficients and standard errors (in brackets) are reported. ** represents significance at the $1 \%$ level, * represents significance at the $5 \%$ level and ${ }^{+}$represents significance at the $10 \%$ level. 
TABLE 5: Employment - Child Dummy Marginal Effect (1993-2003)

\begin{tabular}{|c|c|c|c|c|c|c|c|c|c|c|c|}
\hline & 1550 & 1994 & 1995 & 1996 & 7 & 1550 & 1999 & 2000 & 2001 & 2002 & 2003 \\
\hline Child & $\begin{array}{c}-0.358 \\
{[0.007]^{* *}}\end{array}$ & $\begin{array}{c}-0.367 \\
{[0.007]^{* *}}\end{array}$ & $\begin{array}{c}-0.365 \\
{[0.006]^{* *}}\end{array}$ & $\begin{array}{c}-0.349 \\
{[0.006]^{* *}}\end{array}$ & $\begin{array}{c}-0.329 \\
{[0.006]^{* *}}\end{array}$ & $\begin{array}{c}-0.343 \\
{[0.006]^{* *}}\end{array}$ & $\begin{array}{c}-0.304 \\
{[0.005]^{* *}}\end{array}$ & $\begin{array}{c}-0.266 \\
{[0.005]^{* *}}\end{array}$ & $\begin{array}{c}-0.268 \\
{[0.005]^{* *}}\end{array}$ & $\begin{array}{c}-0.266 \\
{[0.005]^{* *}}\end{array}$ & $\begin{array}{c}-0.28 \\
{[0.005]^{* *}}\end{array}$ \\
\hline Age & $\begin{array}{c}-0.047 \\
{[0.010]^{* *}}\end{array}$ & $\begin{array}{c}-0.026 \\
{[0.010]^{* *}}\end{array}$ & $\begin{array}{c}-0.026 \\
{[0.009]^{* *}}\end{array}$ & $\begin{array}{c}-0.004 \\
{[0.009]}\end{array}$ & $\begin{array}{c}0.01 \\
{[0.008]}\end{array}$ & $\begin{array}{c}0.031 \\
{[0.008]^{* *}}\end{array}$ & $\begin{array}{c}0.007 \\
{[0.008]}\end{array}$ & $\begin{array}{c}0.008 \\
{[0.008]}\end{array}$ & $\begin{array}{c}0.001 \\
{[0.008]}\end{array}$ & $\begin{array}{c}-0.011 \\
{[0.008]}\end{array}$ & $\begin{array}{c}0.002 \\
{[0.008]}\end{array}$ \\
\hline Mediun & $\begin{array}{c}0.008 \\
{[0.010]}\end{array}$ & $\begin{array}{c}-0.01 \\
{[0.011]}\end{array}$ & $\begin{array}{c}-0.005 \\
{[0.009]}\end{array}$ & $\begin{array}{c}-0.033 \\
{[0.009]^{* *}}\end{array}$ & $\begin{array}{c}-0.053 \\
{[0.009]^{* *}}\end{array}$ & $\begin{array}{c}-0.01 \\
{[0.008]}\end{array}$ & $\begin{array}{c}-0.053 \\
{[0.008]^{* *}}\end{array}$ & $\begin{array}{c}-0.055 \\
{[0.008]^{* *}}\end{array}$ & $\begin{array}{c}-0.067 \\
{[0.007]^{* *}}\end{array}$ & $\begin{array}{c}-0.05 \\
{[0.007]^{* *}}\end{array}$ & $\begin{array}{c}-0.044 \\
{[0.007]^{* *}}\end{array}$ \\
\hline Low & $\begin{array}{c}-0.081 \\
{[0.011]^{* *}}\end{array}$ & $\begin{array}{c}-0.103 \\
{[0.011]^{* *}}\end{array}$ & $\begin{array}{c}-0.098 \\
{[0.009]^{* *}}\end{array}$ & $\begin{array}{c}-0.129 \\
{[0.008]^{* *}}\end{array}$ & $\begin{array}{c}-0.164 \\
{[0.008]^{* *}}\end{array}$ & $\begin{array}{c}-0.123 \\
{[0.008]^{* *}}\end{array}$ & $\begin{array}{c}-0.166 \\
{[0.008]^{* *}}\end{array}$ & $\begin{array}{c}-0.184 \\
{[0.008]^{* *}}\end{array}$ & $\begin{array}{c}-0.187 \\
{[0.008]^{* *}}\end{array}$ & $\begin{array}{c}-0.168 \\
{[0.008]^{* *}}\end{array}$ & $\begin{array}{c}-0.171 \\
{[0.008]^{* *}}\end{array}$ \\
\hline No $C$ & $\begin{array}{c}-0.362 \\
{[0.013]^{* *}}\end{array}$ & $\begin{array}{c}-0.401 \\
{[0.013]^{* *}}\end{array}$ & $\begin{array}{c}-0.4 \\
{[0.011]^{* *}}\end{array}$ & $\begin{array}{c}-0.428 \\
{[0.011]^{* *}}\end{array}$ & $\begin{array}{c}-0.474 \\
{[0.011]^{* *}}\end{array}$ & $\begin{array}{c}-0.439 \\
{[0.011]^{* *}}\end{array}$ & $\begin{array}{c}-0.48 \\
{[0.010]^{* *}}\end{array}$ & $\begin{array}{c}-0.492 \\
{[0.010]^{* *}}\end{array}$ & $\begin{array}{c}-0.483 \\
{[0.010]^{* *}}\end{array}$ & $\begin{array}{c}-0.484 \\
{[0.010]^{* *}}\end{array}$ & $\begin{array}{c}-0.505 \\
{[0.010]^{* *}}\end{array}$ \\
\hline Black & $\begin{array}{c}-0.118 \\
{[0.016]^{* *}}\end{array}$ & $\begin{array}{c}-0.05 \\
{[0.015]^{* *}}\end{array}$ & $\begin{array}{c}-0.087 \\
{[0.014]^{* *}}\end{array}$ & $\begin{array}{c}-0.109 \\
{[0.014]^{* *}}\end{array}$ & $\begin{array}{c}-0.068 \\
{[0.014]^{* *}}\end{array}$ & $\begin{array}{c}-0.069 \\
{[0.014]^{* *}}\end{array}$ & $\begin{array}{c}-0.076 \\
{[0.014]^{* *}}\end{array}$ & $\begin{array}{c}-0.09 \\
{[0.014]^{* *}}\end{array}$ & $\begin{array}{c}-0.047 \\
{[0.014]^{* *}}\end{array}$ & $\begin{array}{c}-0.067 \\
{[0.014]^{* *}}\end{array}$ & $\begin{array}{c}-0.044 \\
{[0.014]^{* *}}\end{array}$ \\
\hline Asian & $\begin{array}{c}-0.047 \\
{[0.020]^{*}}\end{array}$ & $\begin{array}{c}-0.051 \\
{[0.020]^{*}}\end{array}$ & $\begin{array}{c}-0.052 \\
{[0.020]^{* *}}\end{array}$ & $\begin{array}{c}-0.098 \\
{[0.021]^{* *}}\end{array}$ & $\begin{array}{c}-0.084 \\
{[0.019]^{* *}}\end{array}$ & $\begin{array}{c}-0.087 \\
{[0.019]^{* *}}\end{array}$ & $\begin{array}{c}-0.136 \\
{[0.019]^{* *}}\end{array}$ & $\begin{array}{c}-0.086 \\
{[0.018]^{* *}}\end{array}$ & $\begin{array}{c}-0.088 \\
{[0.017]^{* *}}\end{array}$ & $\begin{array}{c}-0.094 \\
{[0.016]^{* *}}\end{array}$ & $\begin{array}{c}-0.077 \\
{[0.016]^{* *}}\end{array}$ \\
\hline Other Ethn. & $\begin{array}{c}-0.245 \\
{[0.043]^{* *}}\end{array}$ & $\begin{array}{c}-0.104 \\
{[0.042]^{*}}\end{array}$ & $\begin{array}{c}-0.076 \\
{[0.035]^{*}}\end{array}$ & $\begin{array}{c}-0.144 \\
{[0.038]^{* *}}\end{array}$ & $\begin{array}{c}-0.044 \\
{[0.034]}\end{array}$ & $\begin{array}{c}-0.087 \\
{[0.031]^{* *}}\end{array}$ & $\begin{array}{c}-0.108 \\
{[0.034]^{* *}}\end{array}$ & $\begin{array}{c}-0.128 \\
{[0.033]^{* *}}\end{array}$ & $\begin{array}{c}-0.032 \\
{[0.018]+}\end{array}$ & $\begin{array}{c}-0.124 \\
{[0.020]^{* *}}\end{array}$ & $\begin{array}{c}-0.087 \\
{[0.019]^{* *}}\end{array}$ \\
\hline Observations & 27322 & 27534 & 36615 & 36975 & 37539 & 38224 & 38382 & 37654 & 40047 & 39137 & 38258 \\
\hline
\end{tabular}

NOTES: We also control for region of residence, age squared and age cubed. The omitted comparison categories are: No Children, High Qualification, Youngest Child 12-16, White. Analysis restricted to those aged 21 years and older. The coefficients and standard errors (in brackets) are reported. ** represents significance at the $1 \%$ level, * represents significance at the $5 \%$ level and ${ }^{+}$represents significance at the $10 \%$ level. 
TABLE 6: Other Labor-Market Outcome Regressions (1993-2003)

\begin{tabular}{|c|c|c|c|c|}
\hline & \multicolumn{2}{|c|}{ Unemployment } & \multicolumn{2}{|c|}{ Inactivity } \\
\hline Treatment Effect & $\begin{array}{c}\text { No trend } \\
\mathbf{0 . 0 0 2} \\
{[0.002]}\end{array}$ & $\begin{array}{c}\text { Trend } \\
\mathbf{- 0 . 0 1 7} \\
{[\mathbf{0 . 0 0 2}]^{* *}}\end{array}$ & $\begin{array}{c}\text { No Trend } \\
\mathbf{- 0 . 0 3 7} \\
{[\mathbf{0 . 0 0 2}]^{* *}}\end{array}$ & $\begin{array}{c}\text { Trend } \\
\mathbf{0 . 0 0 6} \\
{[\mathbf{0 . 0 0 5}]}\end{array}$ \\
\hline Age & $\begin{array}{c}-0.023 \\
{[0.002]^{* *}}\end{array}$ & $\begin{array}{c}-0.023 \\
{[0.002]^{* *}}\end{array}$ & $\begin{array}{c}-0.03 \\
{[0.003]^{* *}}\end{array}$ & $\begin{array}{c}-0.029 \\
{[0.003] * *}\end{array}$ \\
\hline One Child & $\begin{array}{c}0.029 \\
{[0.003]^{* *}}\end{array}$ & $\begin{array}{c}0.013 \\
{[0.003]^{* *}}\end{array}$ & $\begin{array}{c}0.113 \\
{[0.005]^{* *}}\end{array}$ & $\begin{array}{c}0.158 \\
{[0.007]^{* *}}\end{array}$ \\
\hline Two Children & $\begin{array}{c}0.023 \\
{[0.004]^{* *}}\end{array}$ & $\begin{array}{c}0.007 \\
{[0.004]+}\end{array}$ & $\begin{array}{c}0.208 \\
{[0.007]^{* *}}\end{array}$ & $\begin{array}{c}0.263 \\
{[0.009]^{* *}}\end{array}$ \\
\hline 3 or more Children & $\begin{array}{c}0.024 \\
{[0.004]^{* *}}\end{array}$ & $\begin{array}{c}0.007 \\
{[0.004]+}\end{array}$ & $\begin{array}{c}0.32 \\
{[0.009]^{* *}}\end{array}$ & $\begin{array}{c}0.38 \\
{[0.010]^{* *}}\end{array}$ \\
\hline Medium Qual & $\begin{array}{c}-0.002 \\
{[0.001]}\end{array}$ & $\begin{array}{c}-0.002 \\
{[0.001]+}\end{array}$ & $\begin{array}{c}0.073 \\
{[0.003]^{* *}}\end{array}$ & $\begin{array}{c}0.074 \\
{[0.003]^{* *}}\end{array}$ \\
\hline Low Qual & $\begin{array}{c}0.015 \\
{[0.001]^{* *}}\end{array}$ & $\begin{array}{c}0.014 \\
{[0.001]^{* *}}\end{array}$ & $\begin{array}{c}0.154 \\
{[0.003]^{* *}}\end{array}$ & $\begin{array}{c}0.154 \\
{[0.003]^{* *}}\end{array}$ \\
\hline No Qual & $\begin{array}{c}0.022 \\
{[0.002]^{* *}}\end{array}$ & $\begin{array}{c}0.022 \\
{[0.002]^{* *}}\end{array}$ & $\begin{array}{c}0.447 \\
{[0.004]^{* *}}\end{array}$ & $\begin{array}{c}0.447 \\
{[0.004]^{* *}}\end{array}$ \\
\hline Youngest Child 0-5 & $\begin{array}{c}-0.009 \\
{[0.002]^{* *}}\end{array}$ & $\begin{array}{c}-0.009 \\
{[0.002]^{* *}}\end{array}$ & $\begin{array}{c}0.225 \\
{[0.006]^{* *}}\end{array}$ & $\begin{array}{c}0.226 \\
{[0.006]^{* *}}\end{array}$ \\
\hline Youngest Child 6-11 & $\begin{array}{c}0.015 \\
{[0.003]^{* *}}\end{array}$ & $\begin{array}{c}0.014 \\
{[0.003]^{* *}}\end{array}$ & $\begin{array}{c}0.057 \\
{[0.005]^{* *}}\end{array}$ & $\begin{array}{c}0.058 \\
{[0.005]^{* *}}\end{array}$ \\
\hline Black & $\begin{array}{c}0.062 \\
{[0.003]^{* *}}\end{array}$ & $\begin{array}{c}0.063 \\
{[0.003]^{* *}}\end{array}$ & $\begin{array}{c}-0.013 \\
{[0.003]^{* *}}\end{array}$ & $\begin{array}{c}-0.014 \\
{[0.003]^{* *}}\end{array}$ \\
\hline Asian & $\begin{array}{c}0.054 \\
{[0.004]^{* *}}\end{array}$ & $\begin{array}{c}0.054 \\
{[0.004]^{* *}}\end{array}$ & $\begin{array}{c}0.046 \\
{[0.006]^{* *}}\end{array}$ & $\begin{array}{c}0.046 \\
{[0.006]^{* *}}\end{array}$ \\
\hline Other Ethnicity & $\begin{array}{c}0.053 \\
{[0.006]^{* *}}\end{array}$ & $\begin{array}{c}0.052 \\
{[0.006]^{* *}}\end{array}$ & $\begin{array}{c}0.046 \\
{[0.009] * *}\end{array}$ & $\begin{array}{c}0.046 \\
{[0.009]^{* *}}\end{array}$ \\
\hline Trend & $\begin{array}{c}-0.004 \\
{[0.000]^{* *}}\end{array}$ & $\begin{array}{c}-0.006 \\
{[0.000]^{* *}}\end{array}$ & $\begin{array}{c}-0.001 \\
{[0.000]^{* *}}\end{array}$ & $\begin{array}{c}0.003 \\
{[0.001]^{* *}}\end{array}$ \\
\hline Post 2000 & $\begin{array}{c}-0.001 \\
{[0.002]}\end{array}$ & $\begin{array}{c}0.007 \\
{[0.002]^{* *}}\end{array}$ & $\begin{array}{c}0.027 \\
{[0.003]^{* *}}\end{array}$ & $\begin{array}{c}0.005 \\
{[0.003]}\end{array}$ \\
\hline Trend_Child & & $\begin{array}{c}0.004 \\
{[0.000]^{* *}}\end{array}$ & & $\begin{array}{c}-0.01 \\
{[0.001]^{* *}}\end{array}$ \\
\hline Observations & 297969 & 297969 & 297969 & 297969 \\
\hline
\end{tabular}

NOTES: We also control for region of residence, age squared and age cubed. The omitted comparison categories are: No Children, High Qualification, Youngest Child 12-16, White. Analysis restricted to those aged 21 years and older. The coefficients and standard errors (in brackets) are reported. ** represents significance at the $1 \%$ level, * represents significance at the $5 \%$ level and ${ }^{+}$represents significance at the $10 \%$ level. 
Figure 1: Average Income by Family Type

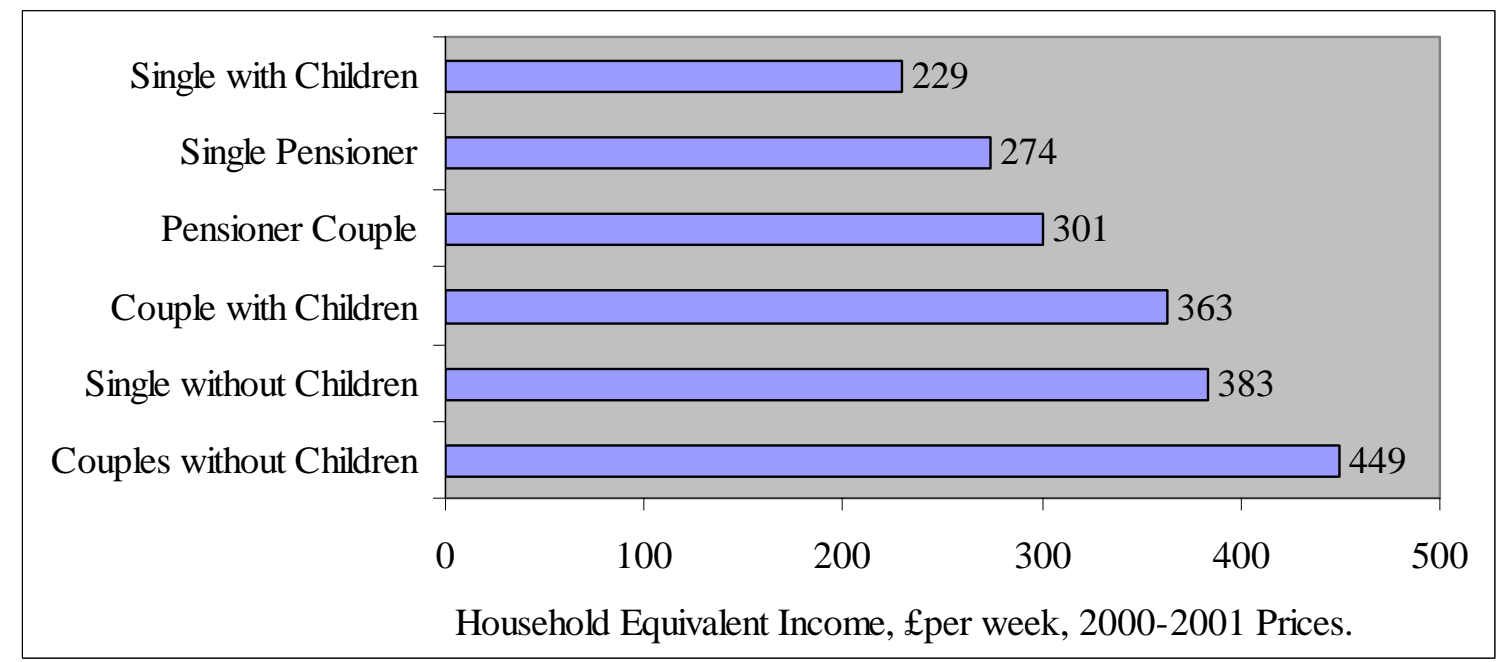

Source - Goodman \& Shephard (2002)

Figure 2: Cross-Country Single Parent Employment Rates

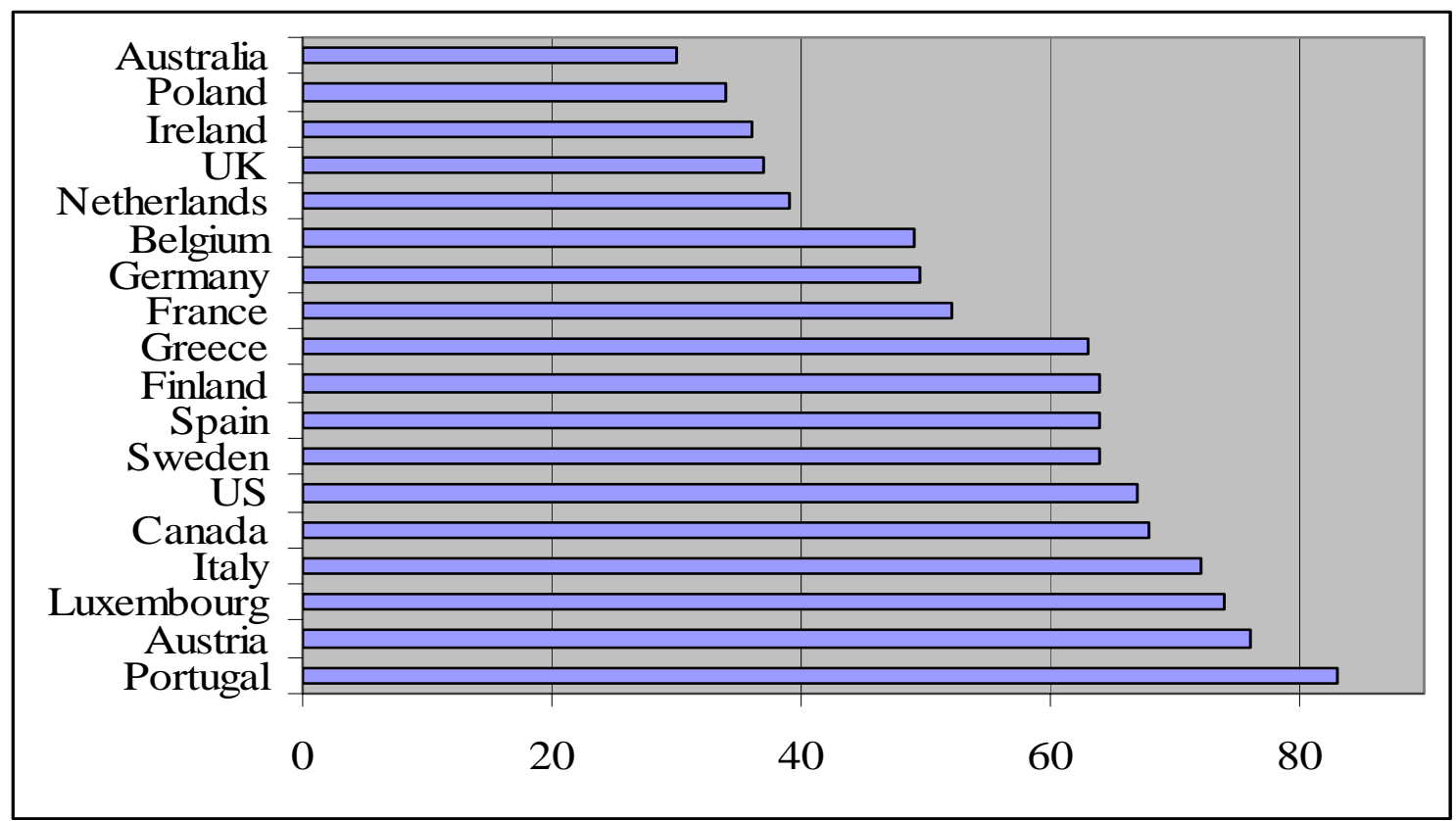

Source: Gregg \& Harkness (2004), OECD Economic Outlook 2001. 
Figure 3: Employment Rate of Single Childless Women and Single Mothers

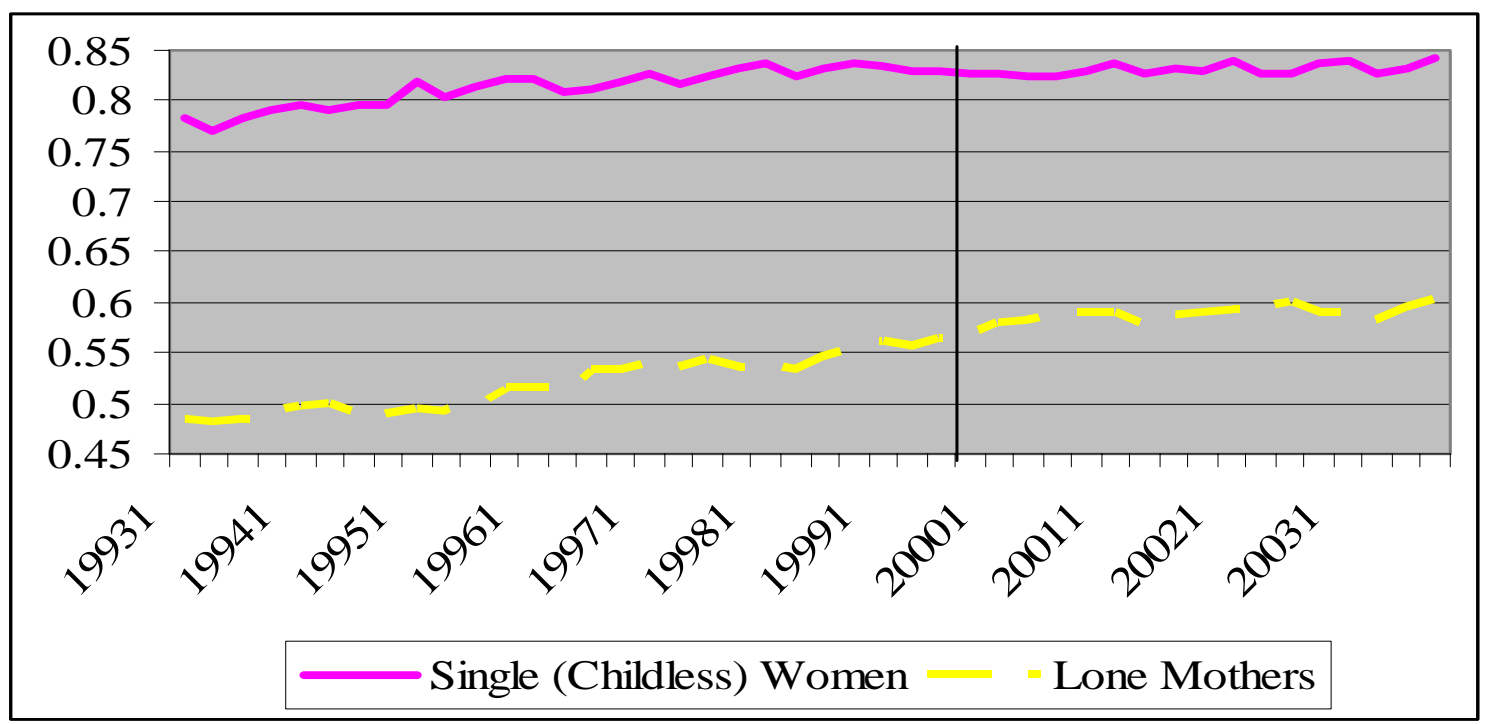

Source - UK Labour Force Survey

Figure 4a: Hours Distribution: Single Mothers

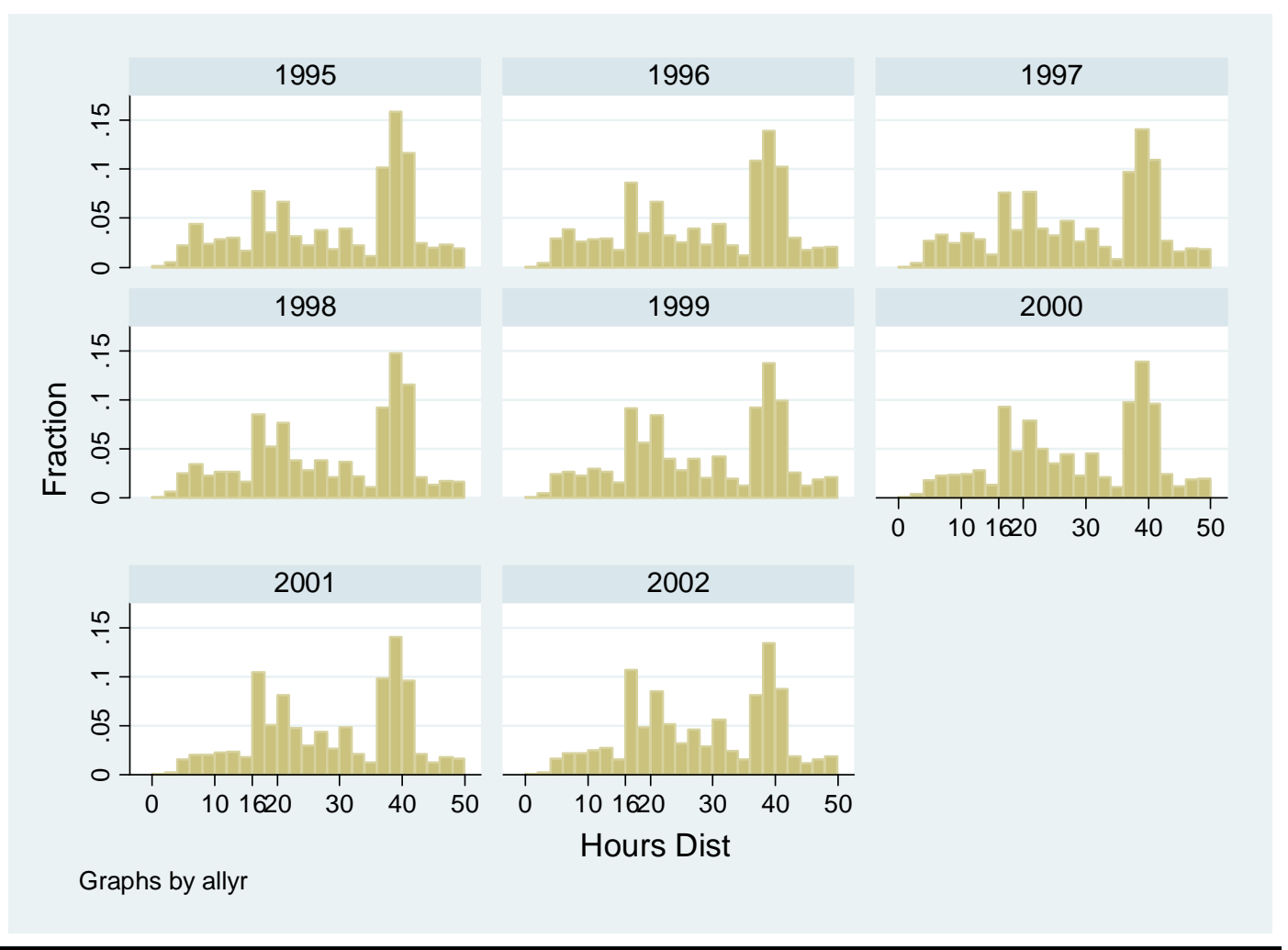

Source - UK Labour Force Survey 
Figure 4 b: Hours Distribution: Single (Childless) Women

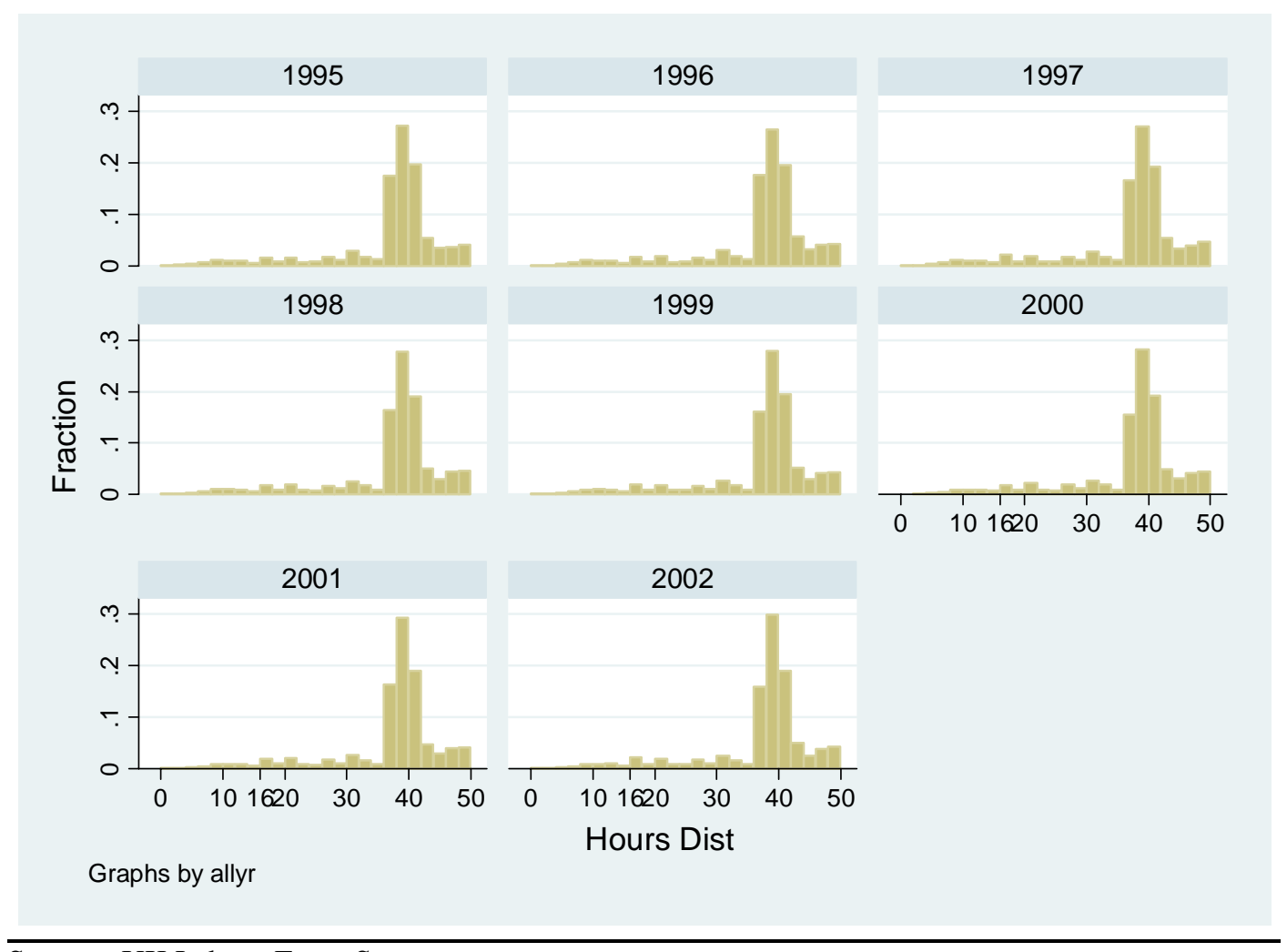

Source - UK Labour Force Survey

Figure 5a: Proportion Working 0-15 Hours

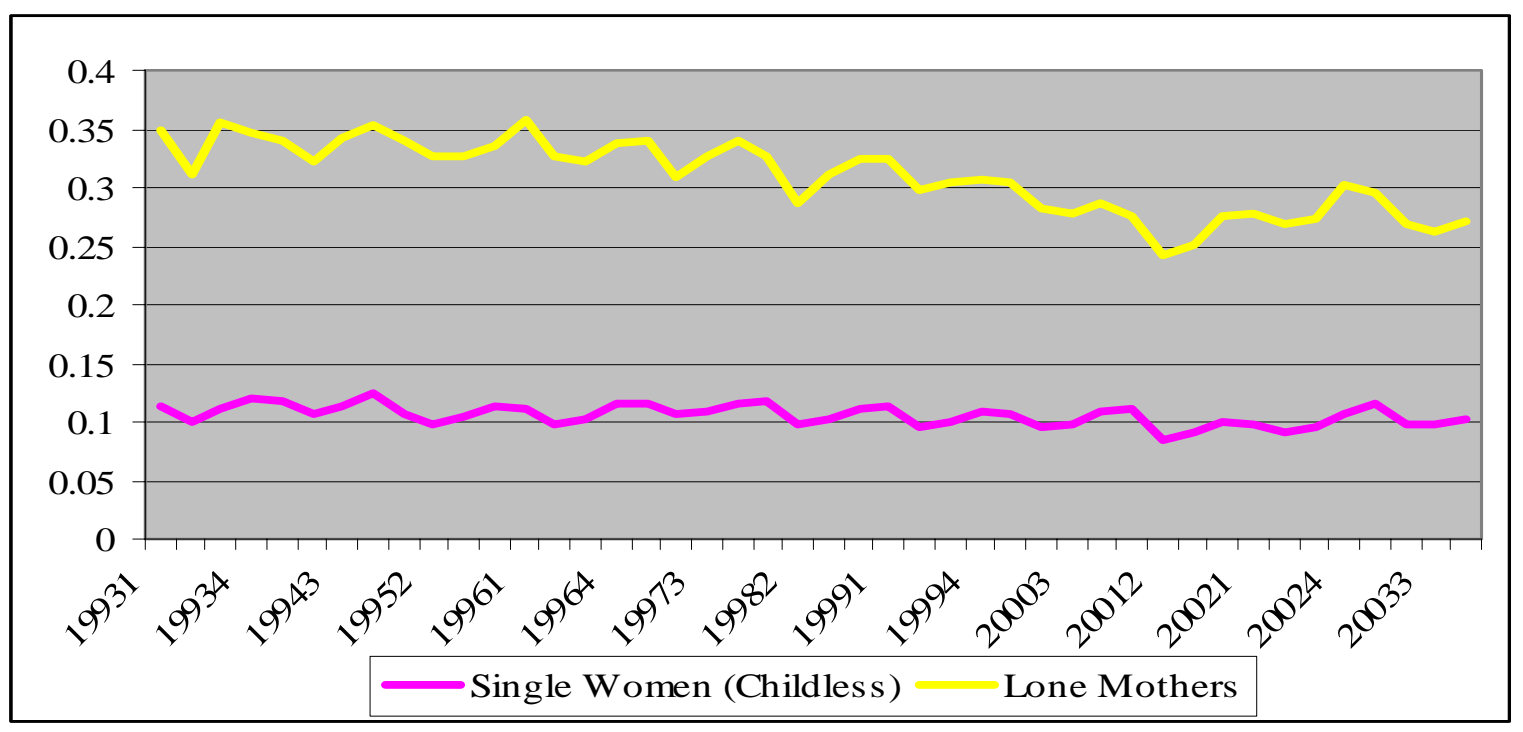


Figure 5b: Proportion Working 16-29 Hours

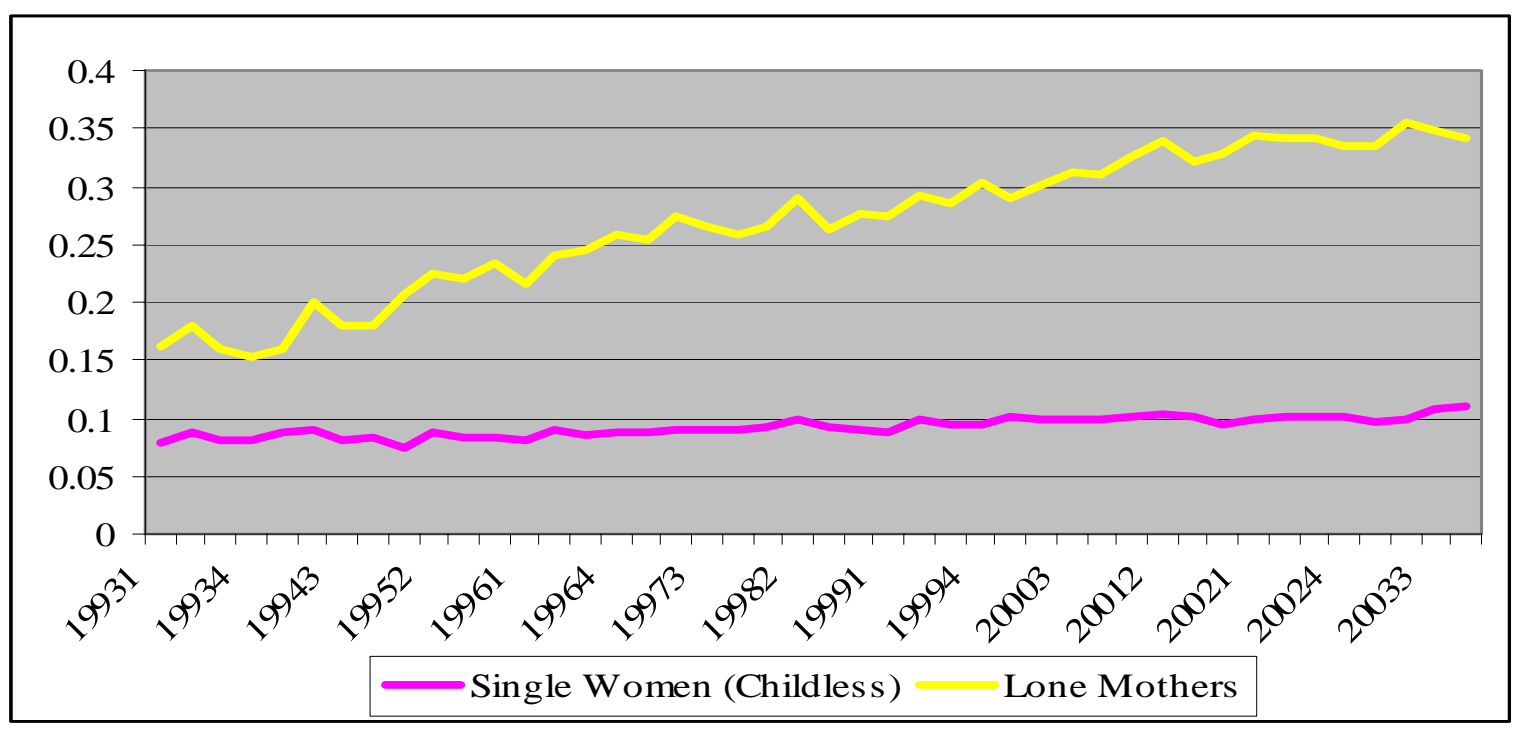

Figure 5c: Proportion Working 30+ Hours

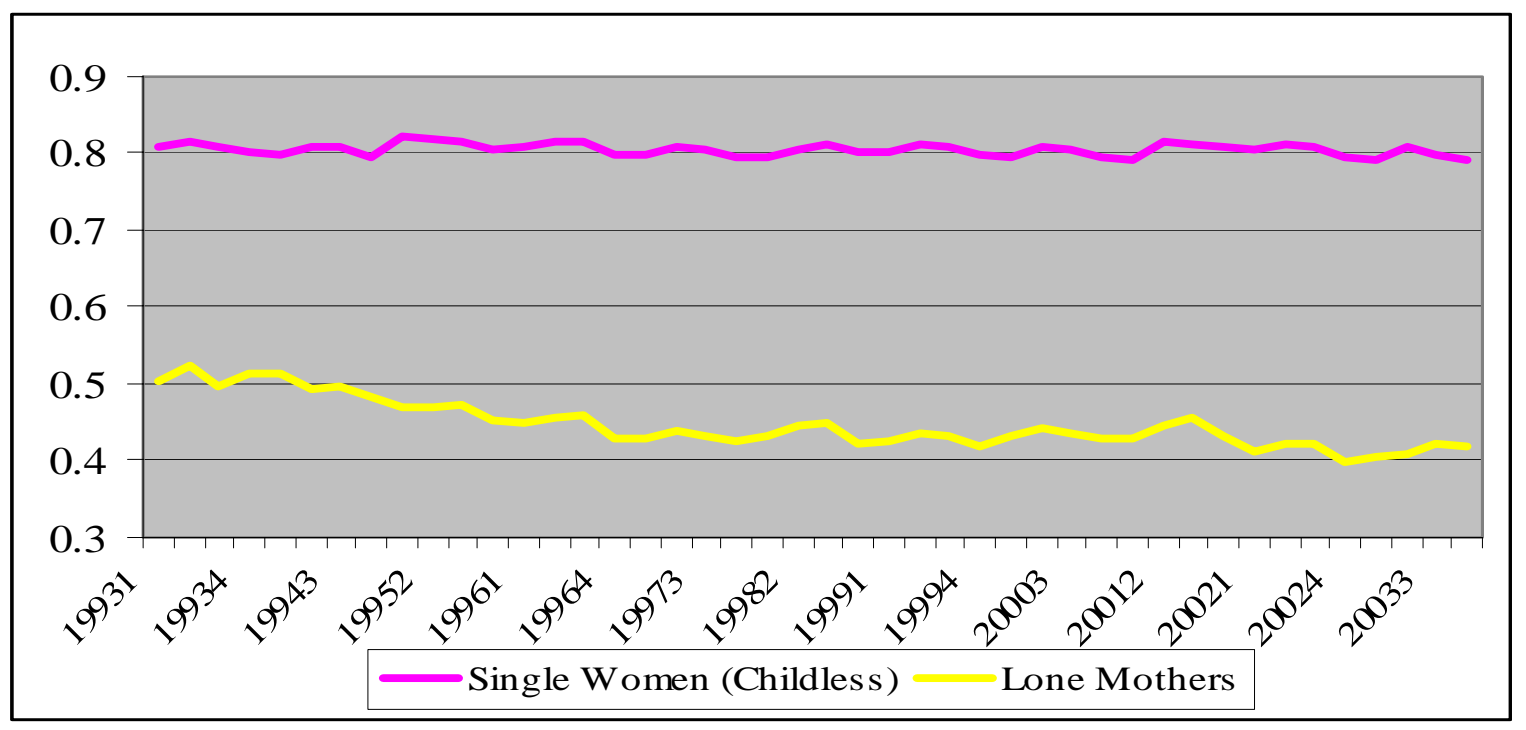


Figure 6: Generosity Change from Family Credit to WFTC

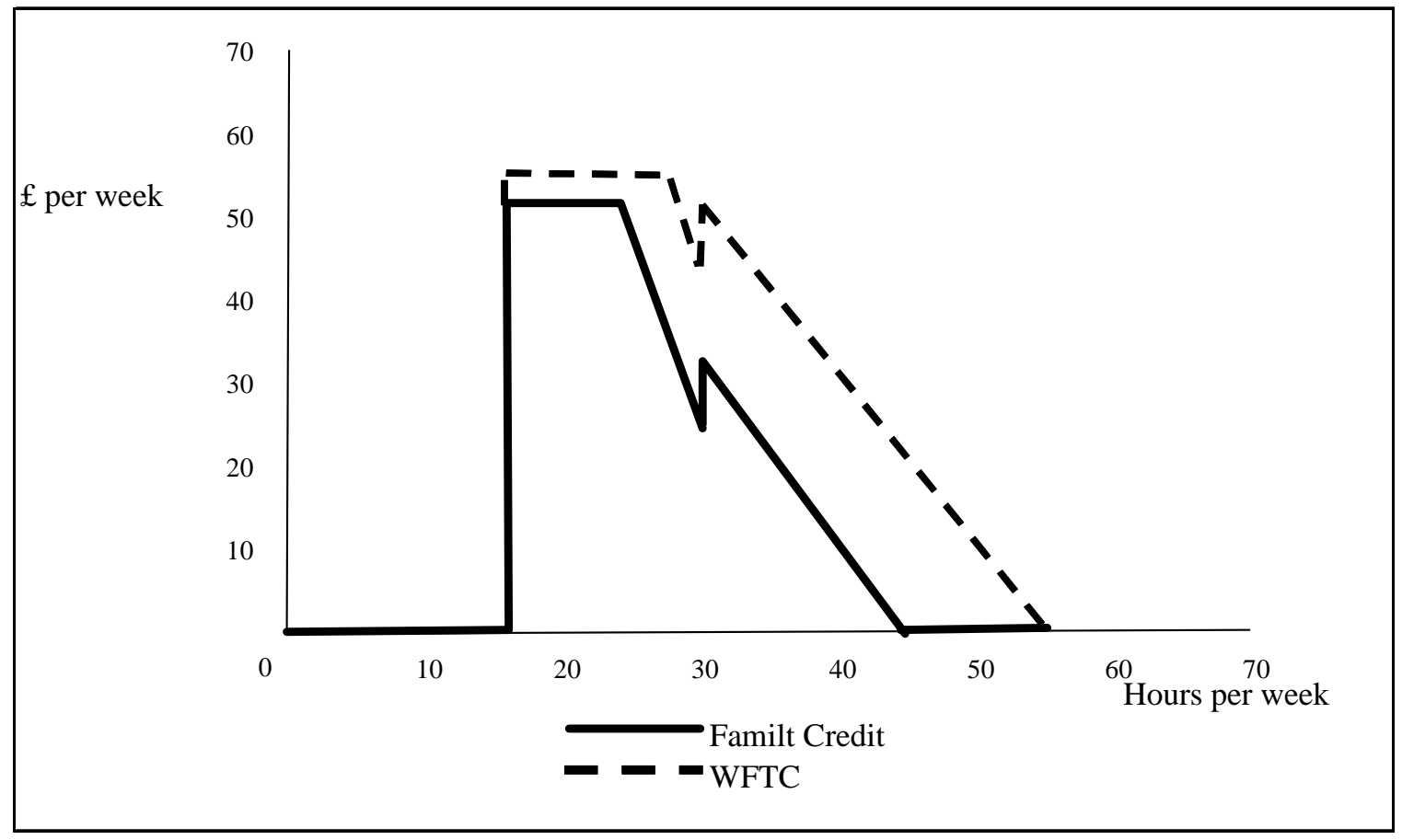

Source - Blundell \& Walker (2001)

Figure 7: Budget Constraint for Single Mothers

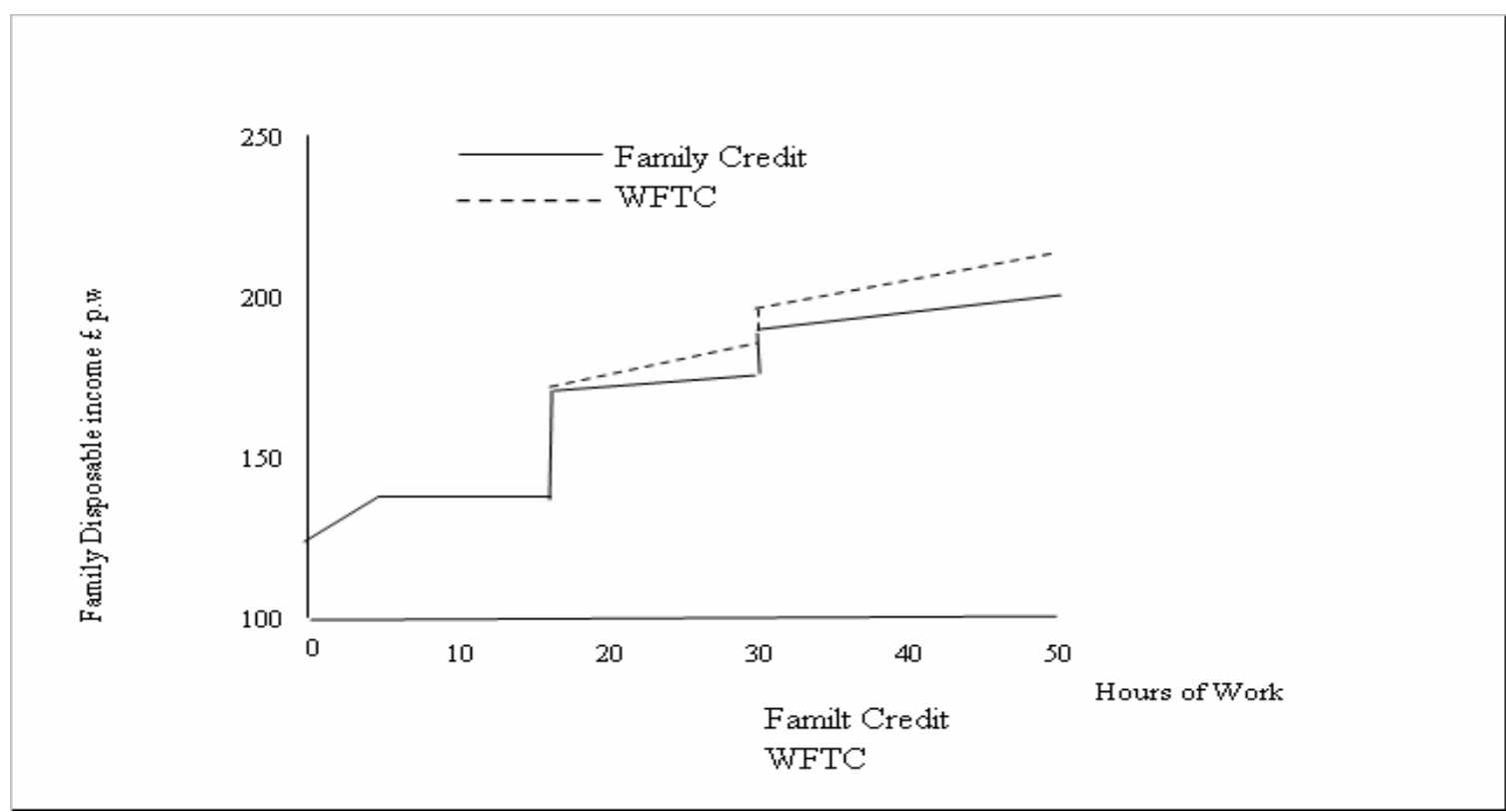

Source - Blundell et al (2000)One child aged under 11. Hourly wage $£ 4.39$ (median for single mother), rent $£ 41.10$ p.w. (median for social renters with children). No childcare costs. 
Figure 8: Employment Rates for Single Mothers

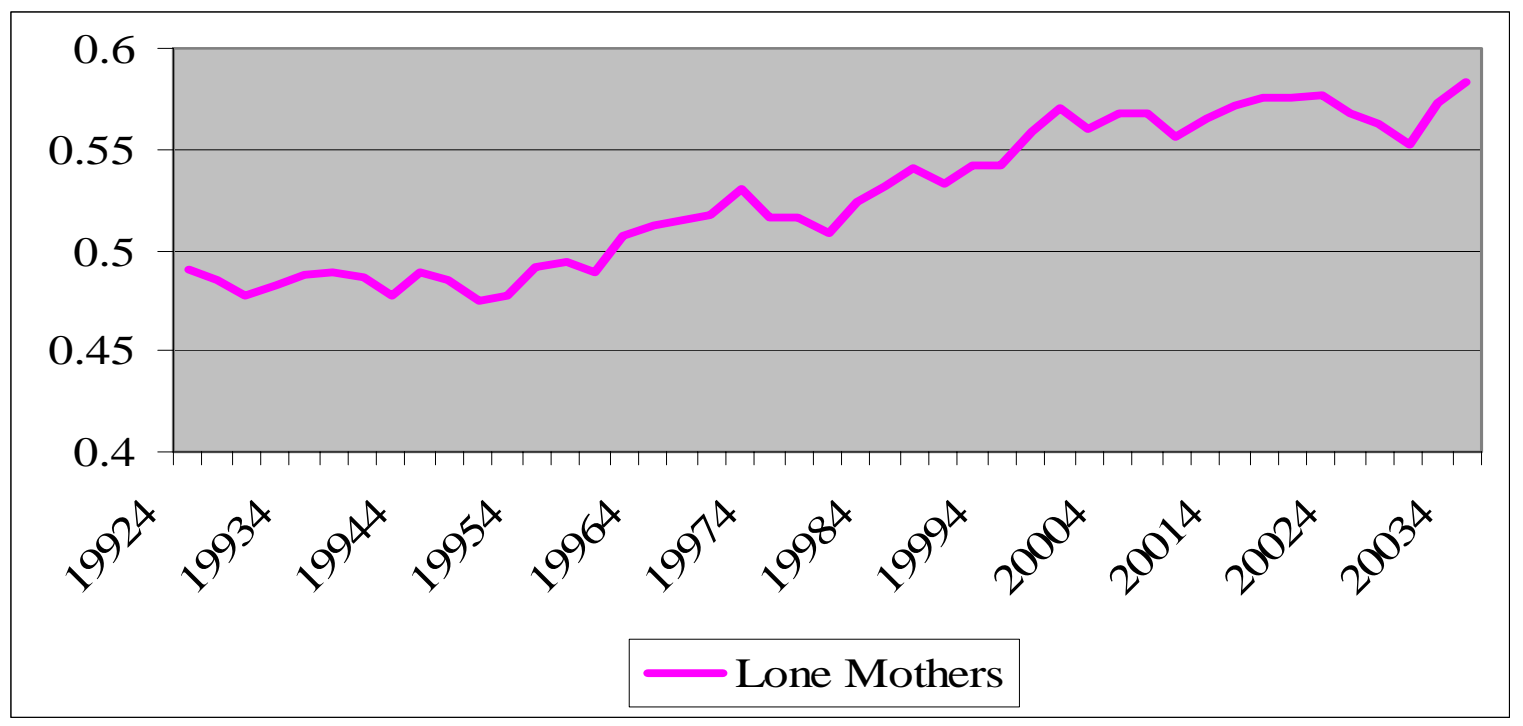

Figure 9: Employment - Child Marginal Effect

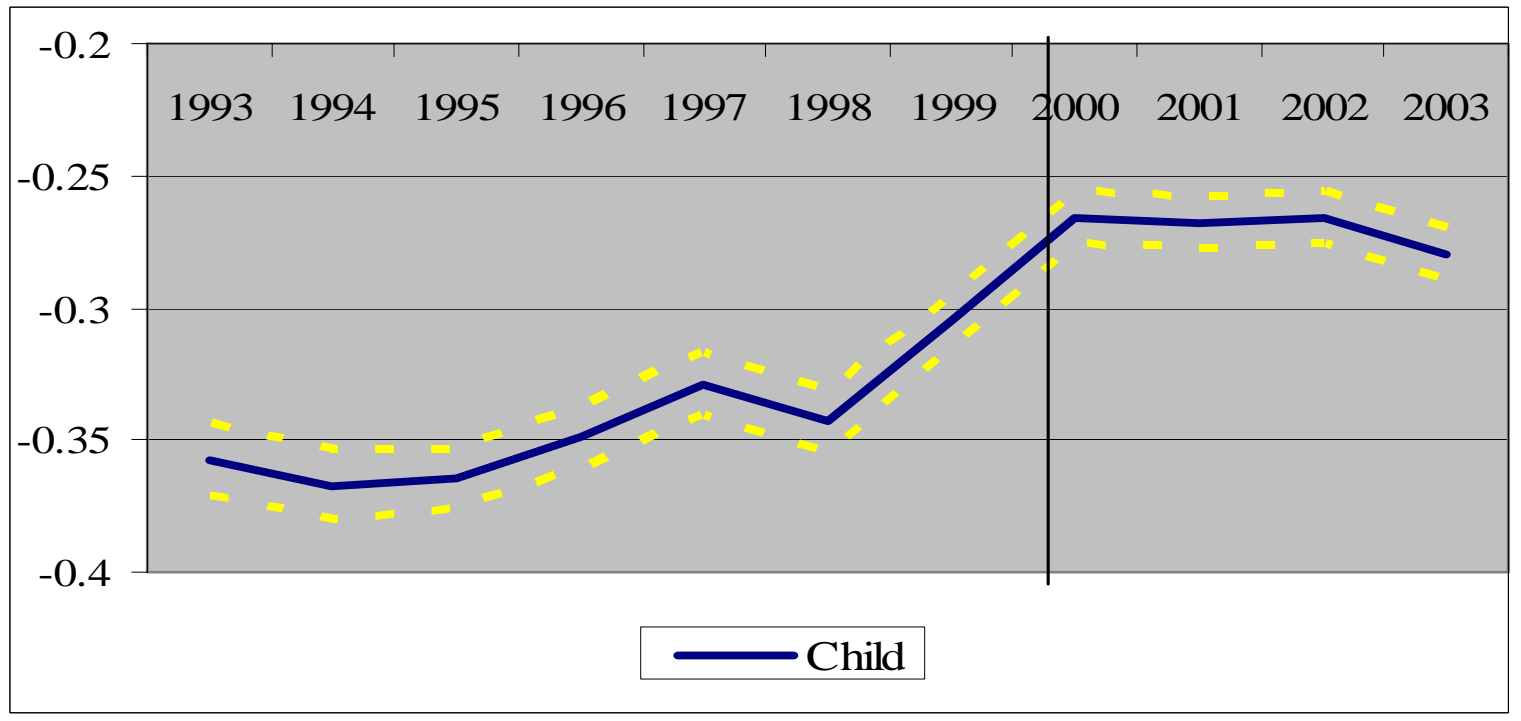


Figure 10: Employment - Age of Youngest Child Marginal Effect

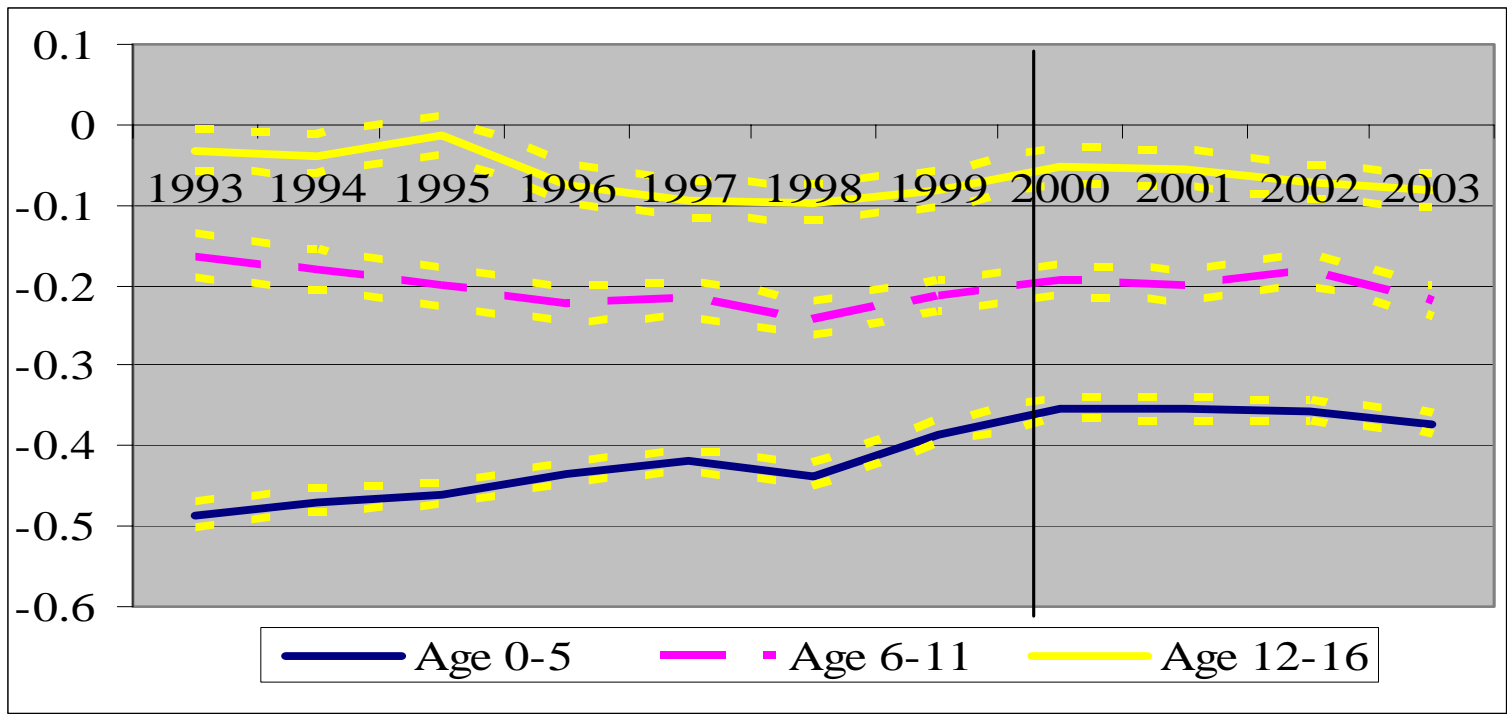

Figure 11: Employment - Number of Children Marginal Effect

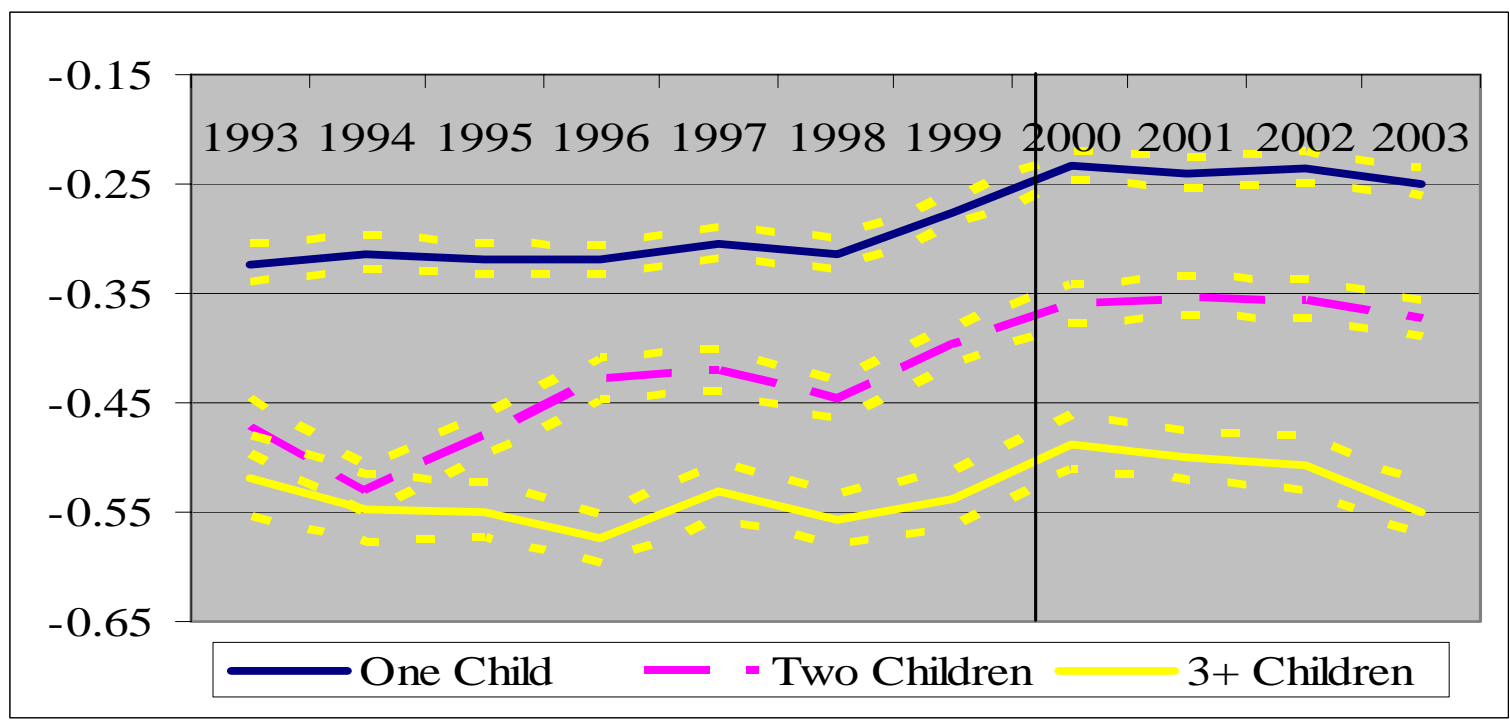


Figure 12: Employment - Highest Qual. (Interacted with Child) Marginal Effect

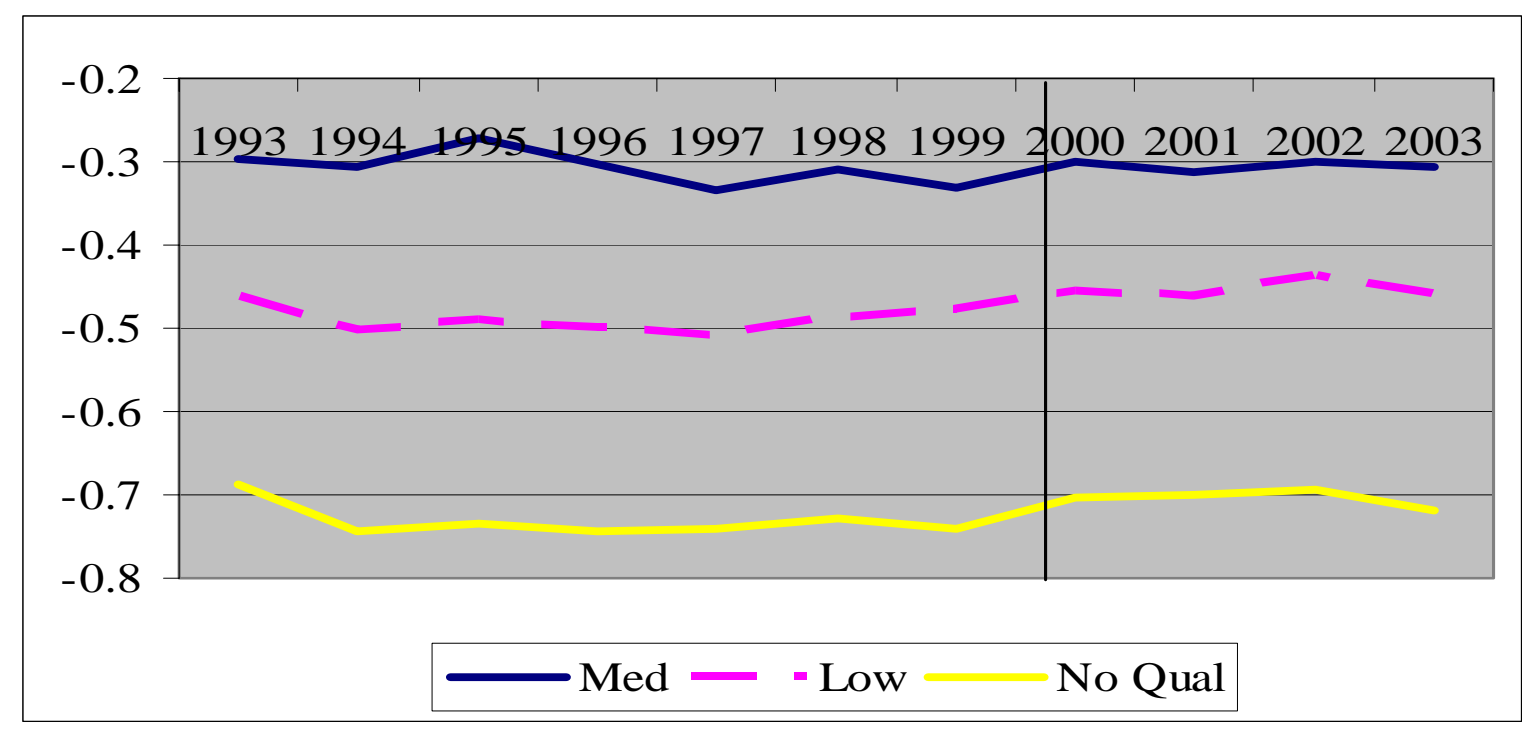

Figure 13a: Work 0-15 Hours - Child Marginal Effect

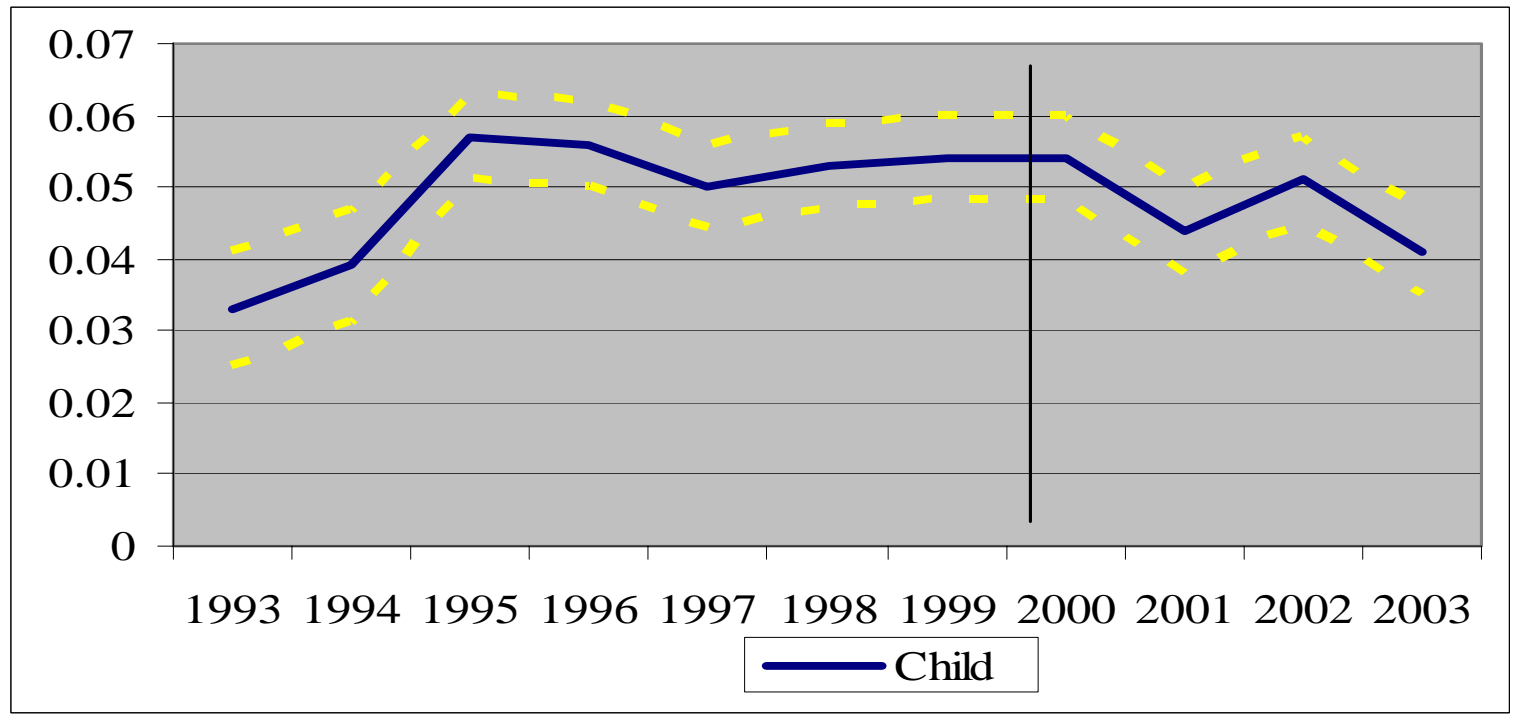

Notes: The dotted line represents a 95\% confidence interval. 
Figure 13b: Work 16-29 Hours - Child Marginal Effect

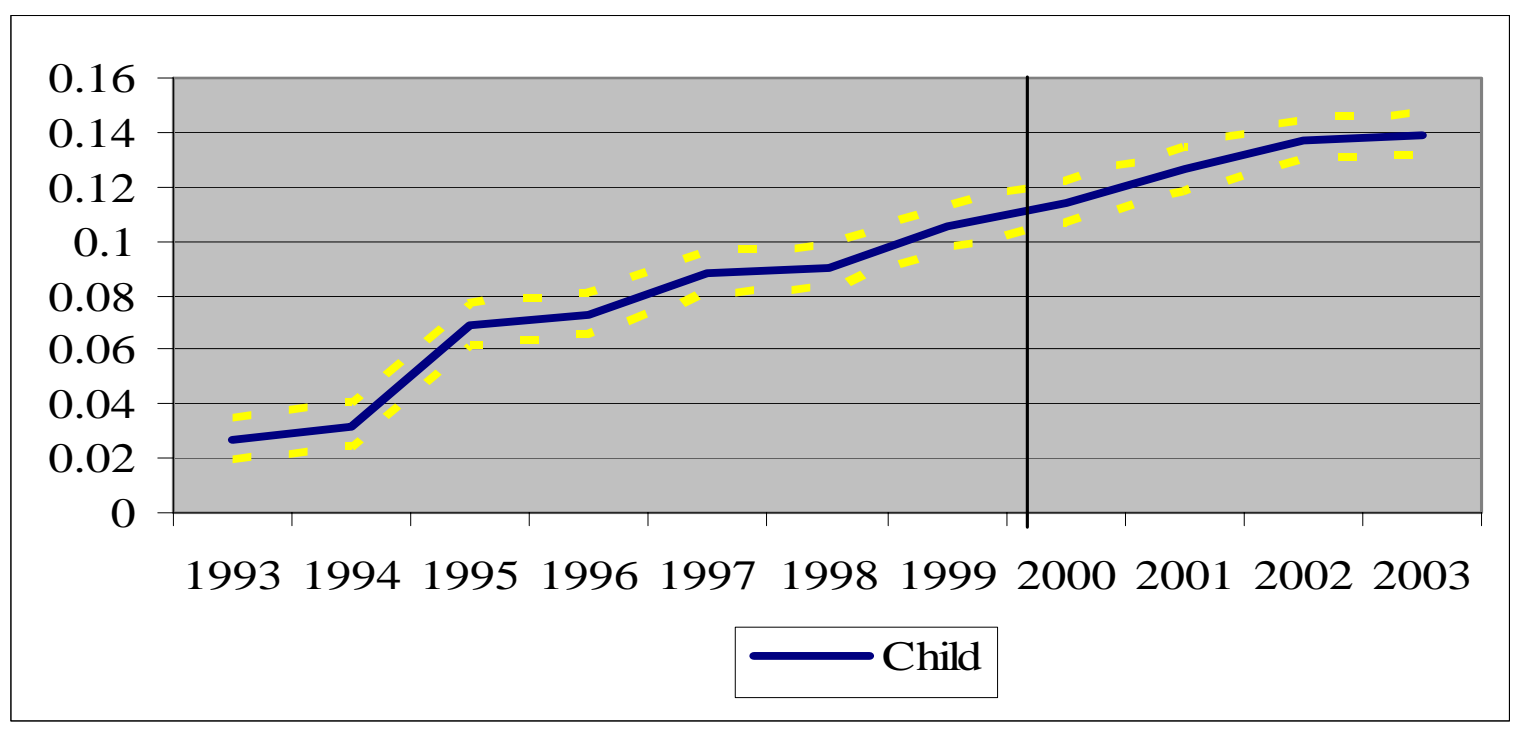

Notes: The dotted line represents a 95\% confidence interval.

Figure 13c: Work 30+ Hours - Child Marginal Effect

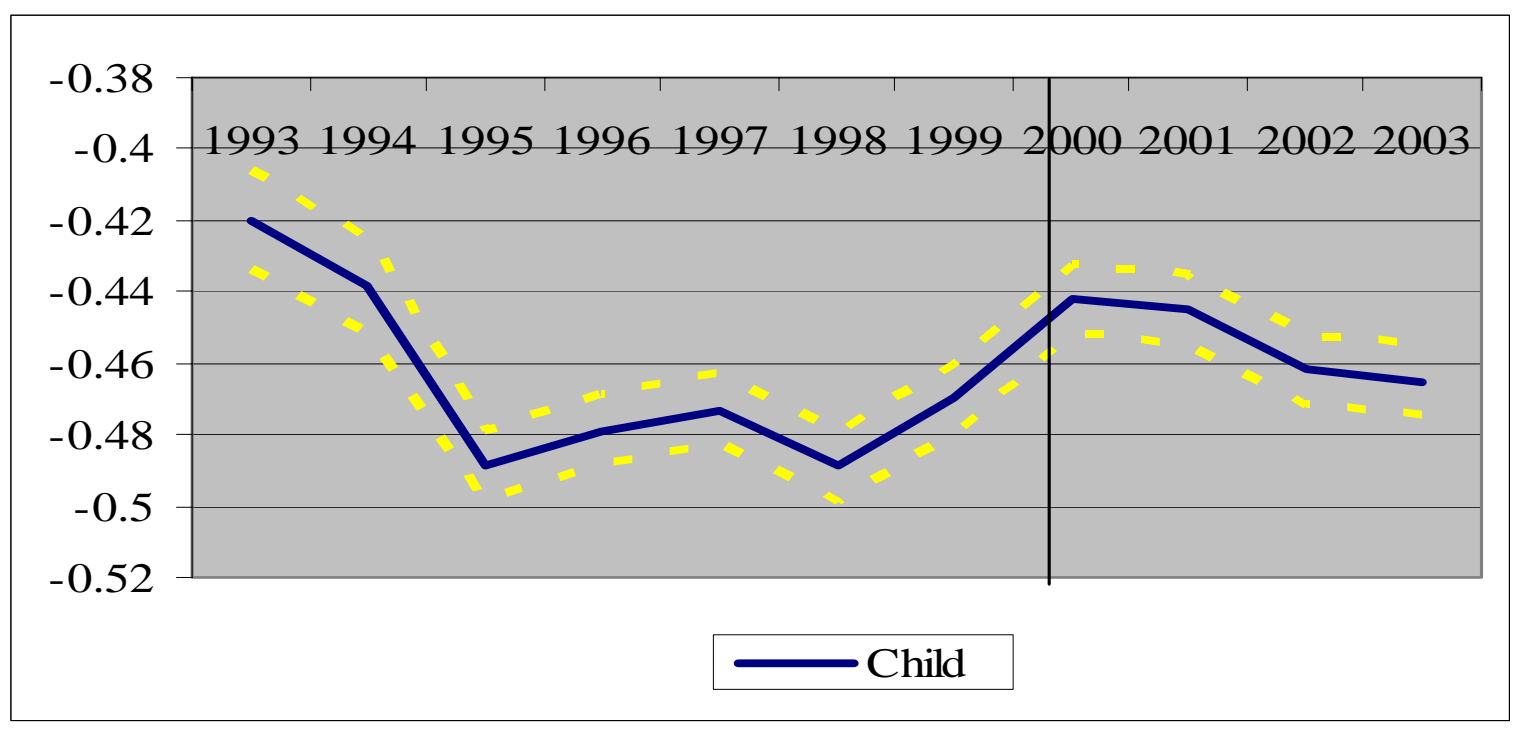

Notes: The dotted line represents a 95\% confidence interval. 
Figure 14a: Unemployment - Child Marginal Effect

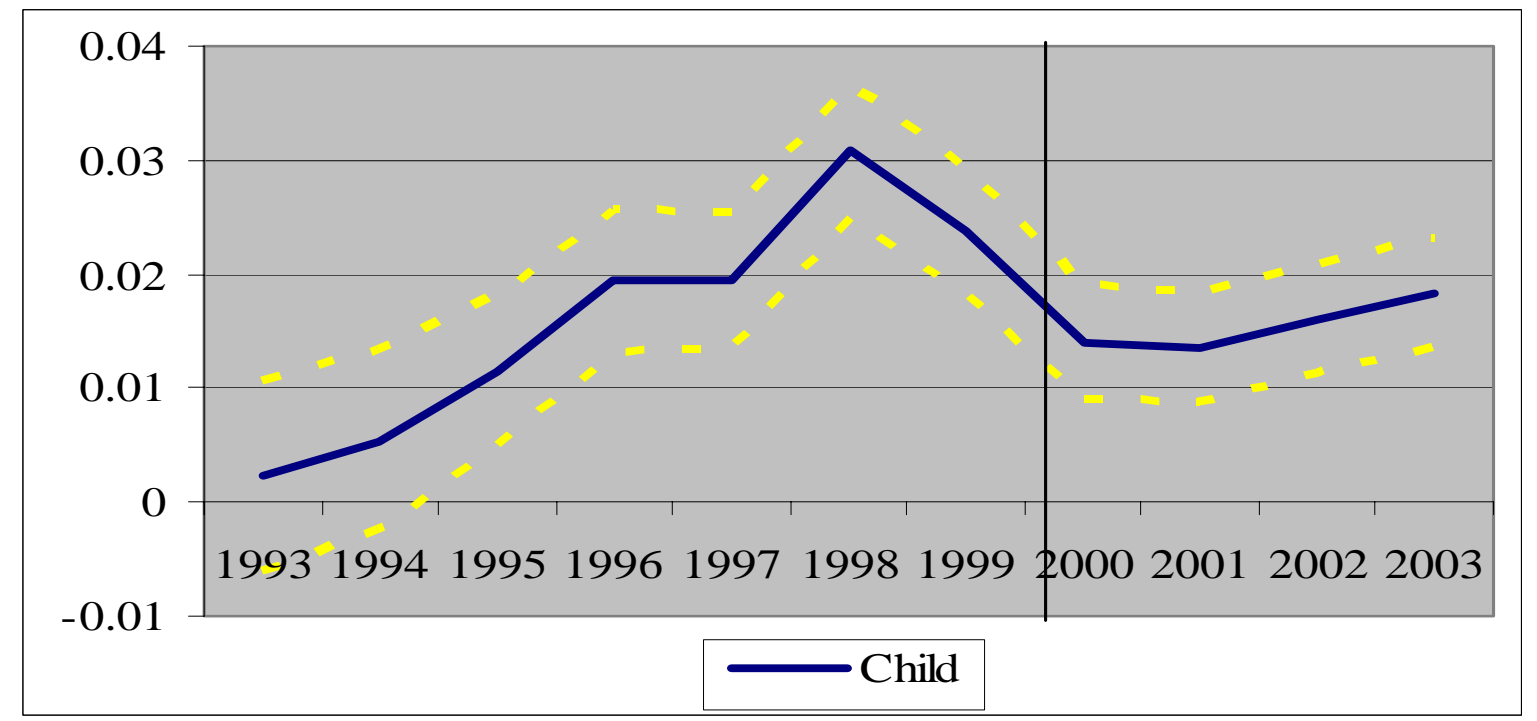

Notes: The dotted line represents a 95\% confidence interval.

Figure 14b: Inactivity - Child Marginal Effect

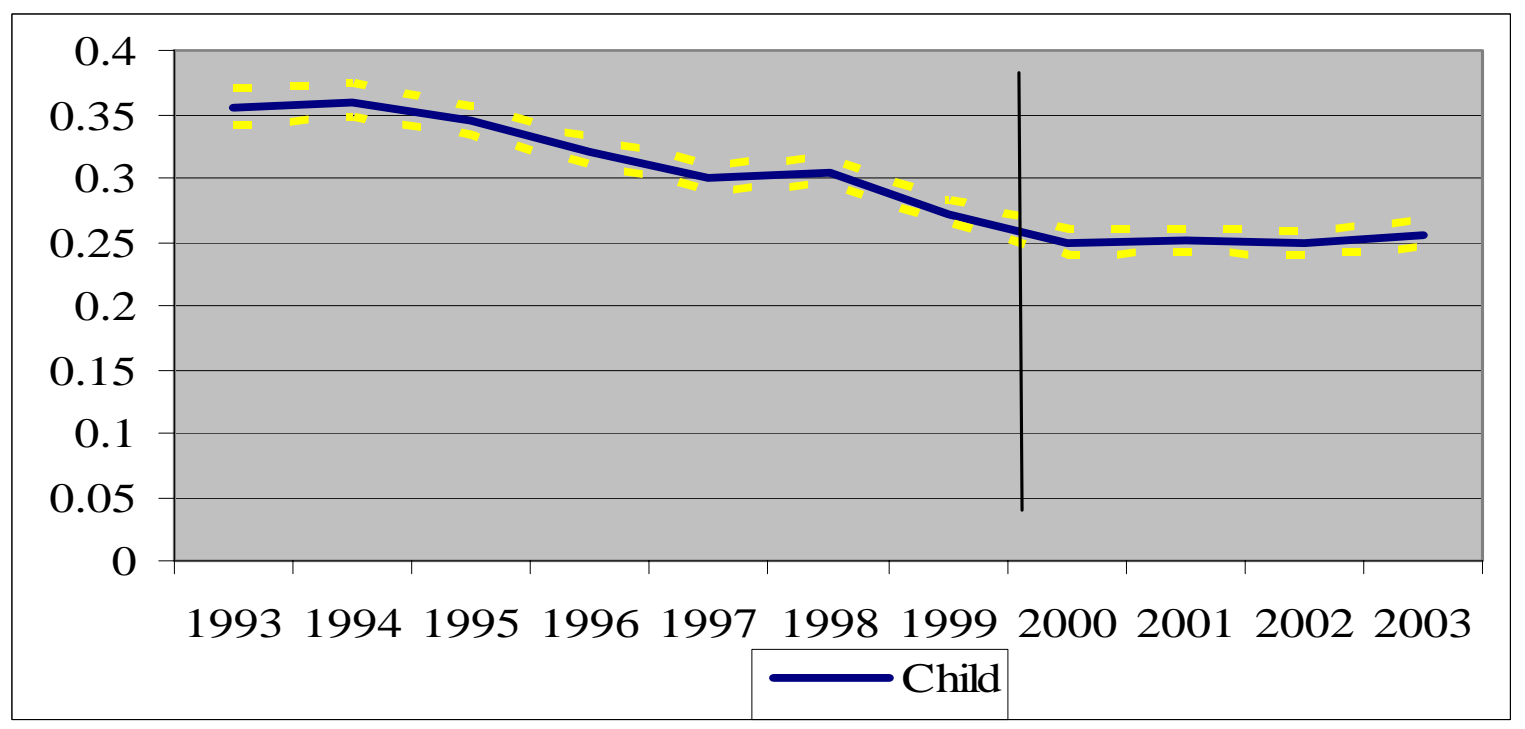

Notes: The dotted line represents a 95\% confidence interval. 


\section{Appendix:}

Table A1: Average Hours Worked (\% in each group) (1995-2003)

\begin{tabular}{|c|c|c|c|c|c|c|c|c|c|c|c|c|c|c|c|c|c|c|c|}
\hline \multirow[b]{2}{*}{ Hours } & \multicolumn{9}{|c|}{ Single Mothers } & \multirow[b]{2}{*}{ Hours } & \multicolumn{9}{|c|}{ Single (Childless) Women } \\
\hline & 1995 & 1996 & 1997 & 1998 & 1999 & 2000 & 2001 & 2002 & 2003 & & 1995 & 1996 & 1997 & 1998 & 1999 & 2000 & 2001 & 2002 & 2003 \\
\hline $0-1$ & 0.13 & 0.04 & 0.06 & 0.09 & 0.06 & 0.03 & 0.07 & 0.03 & 0.01 & $0-1$ & 0.03 & 0.03 & 0.06 & 0.01 & 0.03 & 0 & 0.02 & 0.01 & 0.01 \\
\hline $2-3$ & 0.49 & 0.47 & 0.46 & 0.65 & 0.5 & 0.45 & 0.29 & 0.26 & 0.17 & $2-3$ & 0.17 & 0.11 & 0.14 & 0.13 & 0.14 & 0.11 & 0.08 & 0.06 & 0.05 \\
\hline $4-5$ & 2.21 & 2.95 & 2.73 & 2.53 & 2.45 & 1.84 & 1.59 & 1.67 & 1.61 & $4-5$ & 0.44 & 0.4 & 0.39 & 0.32 & 0.39 & 0.33 & 0.28 & 0.35 & 0.41 \\
\hline $6-7$ & 4.43 & 3.86 & 3.33 & 3.51 & 2.72 & 2.33 & 2.09 & 2.18 & 2.17 & $6-7$ & 0.72 & 0.68 & 0.63 & 0.6 & 0.6 & 0.46 & 0.56 & 0.54 & 0.65 \\
\hline 8-9 & 2.36 & 2.6 & 2.43 & 2.34 & 2.29 & 2.36 & 2.06 & 2.25 & 2.08 & 8-9 & 1.16 & 1.08 & 1.13 & 1.04 & 0.89 & 0.98 & 0.98 & 0.9 & 0.98 \\
\hline $10-11$ & 2.85 & 2.85 & 3.49 & 2.7 & 3 & 2.44 & 2.29 & 2.54 & 2.54 & $10-11$ & 0.96 & 0.99 & 1 & 1.04 & 1.07 & 0.94 & 0.91 & 0.96 & 0.85 \\
\hline $12-13$ & 2.97 & 2.91 & 2.83 & 2.69 & 2.68 & 2.87 & 2.33 & 2.75 & 2.3 & $12-13$ & 1.02 & 0.98 & 1.03 & 0.98 & 0.98 & 0.99 & 0.97 & 1.08 & 1.23 \\
\hline $14-15$ & 1.65 & 1.76 & 1.32 & 1.65 & 1.63 & 1.35 & 1.8 & 1.6 & 1.71 & $14-15$ & 0.55 & 0.58 & 0.65 & 0.61 & 0.71 & 0.75 & 0.65 & 0.61 & 0.77 \\
\hline $16-17$ & 7.8 & 8.66 & 7.64 & 8.52 & 9.15 & 9.35 & 10.47 & 10.69 & 10.16 & $16-17$ & 1.59 & 1.69 & 2.07 & 1.77 & 1.97 & 1.89 & 1.93 & 2.19 & 2.39 \\
\hline $18-19$ & 3.54 & 3.45 & 3.81 & 5.27 & 5.66 & 4.83 & 5.13 & 4.89 & 5.02 & $18-19$ & 0.79 & 0.87 & 0.89 & 0.95 & 0.91 & 0.98 & 1.02 & 0.91 & 0.94 \\
\hline $20-21$ & 6.67 & 6.65 & 7.73 & 7.71 & 8.47 & 7.92 & 8.18 & 8.51 & 8.51 & $20-21$ & 1.52 & 1.79 & 1.88 & 1.93 & 1.8 & 2.22 & 2.04 & 1.91 & 2.15 \\
\hline $22-23$ & 3.14 & 3.24 & 3.94 & 3.86 & 4.02 & 5.01 & 4.76 & 5.15 & 5.18 & $22-23$ & 0.67 & 0.74 & 0.79 & 1.01 & 0.89 & 1.02 & 0.92 & 0.98 & 0.94 \\
\hline $24-25$ & 2.26 & 2.56 & 3.23 & 2.88 & 2.85 & 3.55 & 3.02 & 3.23 & 4.05 & $24-25$ & 0.75 & 0.78 & 0.86 & 0.77 & 0.89 & 0.76 & 0.85 & 0.88 & 0.89 \\
\hline $26-27$ & 3.8 & 3.96 & 4.72 & 3.83 & 3.99 & 4.52 & 4.4 & 4.64 & 4.91 & $26-27$ & 1.74 & 1.61 & 1.66 & 1.75 & 1.73 & 1.97 & 1.75 & 1.79 & 1.8 \\
\hline $28-29$ & 1.86 & 2.28 & 2.58 & 2.16 & 2.07 & 2.32 & 2.69 & 2.96 & 2.63 & $28-29$ & 1.15 & 1.17 & 1.12 & 1.26 & 1.17 & 1.2 & 1.14 & 1.03 & 1.02 \\
\hline 30-31 & 3.94 & 4.39 & 3.96 & 3.72 & 4.29 & 4.55 & 4.9 & 5.65 & 6 & $30-31$ & 2.88 & 2.99 & 2.77 & 2.64 & 2.68 & 2.78 & 2.67 & 2.57 & 3.07 \\
\hline $32-33$ & 2.26 & 2.26 & 2.04 & 2.23 & 2 & 2.17 & 2.17 & 2.46 & 2.28 & $32-33$ & 1.76 & 1.79 & 1.63 & 1.82 & 1.87 & 2.01 & 1.69 & 1.66 & 1.54 \\
\hline $34-35$ & 1.14 & 1.19 & 0.82 & 1.12 & 1.25 & 1.16 & 1.32 & 1.55 & 1.36 & $34-35$ & 1.26 & 1.24 & 1.12 & 0.93 & 0.95 & 1.01 & 0.91 & 0.88 & 1.01 \\
\hline $36-37$ & 10.19 & 10.91 & 9.74 & 9.24 & 9.26 & 9.76 & 9.85 & 8.16 & 9.4 & $36-37$ & 17.38 & 17.53 & 16.51 & 16.47 & 16.07 & 15.57 & 16.34 & 16 & 16.5 \\
\hline 38-39 & 15.92 & 13.91 & 14.09 & 14.77 & 13.76 & 13.95 & 14.07 & 13.48 & 13.18 & 38-39 & 27.21 & 26.46 & 26.99 & 27.71 & 27.88 & 28.16 & 29.32 & 29.87 & 28.82 \\
\hline $40-41$ & 11.66 & 10.24 & 10.95 & 11.59 & 9.95 & 9.61 & 9.6 & 8.77 & 8.66 & $40-41$ & 19.68 & 19.51 & 19.22 & 19.11 & 19.55 & 19.15 & 18.96 & 19.04 & 19.14 \\
\hline $42-43$ & 2.47 & 2.99 & 2.7 & 2.11 & 2.58 & 2.48 & 2.17 & 1.89 & 1.79 & $42-43$ & 5.39 & 5.63 & 5.43 & 5.09 & 5.22 & 4.9 & 4.81 & 5.06 & 4.37 \\
\hline $44-45$ & 2.02 & 1.8 & 1.64 & 1.39 & 1.28 & 1.25 & 1.28 & 1.21 & 1.02 & $44-45$ & 3.47 & 3.16 & 3.38 & 3.05 & 3.08 & 3.17 & 2.96 & 2.57 & 2.47 \\
\hline $46-47$ & 2.32 & 1.99 & 1.95 & 1.76 & 1.92 & 1.89 & 1.82 & 1.57 & 1.66 & $46-47$ & 3.65 & 4.03 & 3.93 & 4.43 & 4.24 & 4.2 & 4.07 & 3.88 & 3.55 \\
\hline $48-49$ & 0.97 & 1.19 & 0.99 & 0.76 & 1.07 & 1 & 0.77 & 0.93 & 0.78 & $48-49$ & 1.92 & 1.79 & 1.99 & 2.11 & 1.95 & 1.99 & 2.04 & 1.89 & 2.02 \\
\hline $50+$ & 0.95 & 0.9 & 0.82 & 0.95 & 1.09 & 1.03 & 0.91 & 1 & 0.82 & $50+$ & 2.16 & 2.38 & 2.72 & 2.47 & 2.36 & 2.5 & 2.12 & 2.38 & 2.42 \\
\hline
\end{tabular}

NOTES: Data taken from the UK Labour Force Survey. 
TABLE A.2.: Employment - Age of Youngest Child Marginal Effect (1993-2003)

\begin{tabular}{|c|c|c|c|c|c|c|c|c|c|c|c|}
\hline & 1993 & 1994 & 1995 & 1996 & 1997 & 1998 & 1999 & 2000 & 2001 & 2002 & 2003 \\
\hline Your & $\begin{array}{c}-0.486 \\
{[0.008]^{* *}}\end{array}$ & $\begin{array}{c}-0.469 \\
{[0.008]^{* *}}\end{array}$ & $\begin{array}{c}-0.461 \\
{[0.007]^{* *}}\end{array}$ & $\begin{array}{c}-0.434 \\
{[0.007]^{* *}}\end{array}$ & $\begin{array}{c}-0.419 \\
{[0.007]^{* *}}\end{array}$ & $\begin{array}{c}-0.437 \\
{[0.007]^{* *}}\end{array}$ & $\begin{array}{c}-0.385 \\
{[0.007]^{* *}}\end{array}$ & $\begin{array}{c}-0.353 \\
{[0.007]^{* *}}\end{array}$ & $\begin{array}{c}-0.355 \\
{[0.007]^{* *}}\end{array}$ & $\begin{array}{c}-0.357 \\
{[0.007]^{* *}}\end{array}$ & $\begin{array}{c}-0.373 \\
{[0.007]^{* *}}\end{array}$ \\
\hline Youngest Child 6-11 & $\begin{array}{c}-0.165 \\
{[0.014]^{* *}}\end{array}$ & $\begin{array}{c}-0.183 \\
{[0.013]^{* *}}\end{array}$ & $\begin{array}{c}-0.203 \\
{[0.012]^{* *}}\end{array}$ & $\begin{array}{c}-0.225 \\
{[0.011]^{* *}}\end{array}$ & $\begin{array}{c}-0.218 \\
{[0.011]^{* *}}\end{array}$ & $\begin{array}{c}-0.243 \\
{[0.011]^{* *}}\end{array}$ & $\begin{array}{c}-0.215 \\
{[0.010]^{* *}}\end{array}$ & $\begin{array}{c}-0.194 \\
{[0.010]^{* *}}\end{array}$ & $\begin{array}{c}-0.2 \\
{[0.010]^{* *}}\end{array}$ & $\begin{array}{c}-0.181 \\
{[0.010]^{* *}}\end{array}$ & $\begin{array}{c}-0.222 \\
{[0.010]^{* *}}\end{array}$ \\
\hline Youngest Child 12-16 & $\begin{array}{c}-0.033 \\
{[0.013]^{*}}\end{array}$ & $\begin{array}{c}-0.038 \\
{[0.013]^{* *}}\end{array}$ & $\begin{array}{c}-0.015 \\
{[0.012]}\end{array}$ & $\begin{array}{c}-0.074 \\
{[0.012]^{* *}}\end{array}$ & $\begin{array}{c}-0.094 \\
{[0.012]^{* *}}\end{array}$ & $\begin{array}{c}-0.098 \\
{[0.012]^{* *}}\end{array}$ & $\begin{array}{c}-0.081 \\
{[0.012]^{* *}}\end{array}$ & $\begin{array}{c}-0.052 \\
{[0.011]^{* *}}\end{array}$ & $\begin{array}{c}-0.056 \\
{[0.011]^{* *}}\end{array}$ & $\begin{array}{c}-0.073 \\
{[0.011]^{* *}}\end{array}$ & $\begin{array}{c}-0.083 \\
{[0.011]^{* *}}\end{array}$ \\
\hline Age & $\begin{array}{c}-0.004 \\
{[0.010]}\end{array}$ & $\begin{array}{c}0.018 \\
{[0.010]+}\end{array}$ & $\begin{array}{c}0.021 \\
{[0.009]^{*}}\end{array}$ & $\begin{array}{c}0.028 \\
{[0.009]^{* *}}\end{array}$ & $\begin{array}{c}0.04 \\
{[0.009]^{* *}}\end{array}$ & $\begin{array}{c}0.063 \\
{[0.008]^{* *}}\end{array}$ & $\begin{array}{c}0.035 \\
{[0.008]^{* *}}\end{array}$ & $\begin{array}{c}0.04 \\
{[0.008]^{* *}}\end{array}$ & $\begin{array}{c}0.034 \\
{[0.008]^{* *}}\end{array}$ & $\begin{array}{c}0.018 \\
{[0.008]^{*}}\end{array}$ & $\begin{array}{c}0.035 \\
{[0.008]^{* *}}\end{array}$ \\
\hline Medium Qual & $\begin{array}{c}0.012 \\
{[0.010]}\end{array}$ & $\begin{array}{c}-0.011 \\
{[0.011]}\end{array}$ & $\begin{array}{c}-0.005 \\
{[0.009]}\end{array}$ & $\begin{array}{c}-0.032 \\
{[0.009]^{* *}}\end{array}$ & $\begin{array}{c}-0.052 \\
{[0.009]^{* *}}\end{array}$ & $\begin{array}{c}-0.006 \\
{[0.008]}\end{array}$ & $\begin{array}{c}-0.05 \\
{[0.008]^{* *}}\end{array}$ & $\begin{array}{c}-0.054 \\
{[0.008]^{* *}}\end{array}$ & $\begin{array}{c}-0.063 \\
{[0.007]^{* *}}\end{array}$ & $\begin{array}{c}-0.049 \\
{[0.007]^{* *}}\end{array}$ & $\begin{array}{c}-0.038 \\
{[0.007]^{* *}}\end{array}$ \\
\hline Low & $\begin{array}{c}-0.064 \\
{[0.011]^{* *}}\end{array}$ & $\begin{array}{c}-0.092 \\
{[0.011]^{* *}}\end{array}$ & $\begin{array}{c}-0.085 \\
{[0.009]^{* *}}\end{array}$ & $\begin{array}{c}-0.114 \\
{[0.008]^{* *}}\end{array}$ & $\begin{array}{c}-0.15 \\
{[0.009]^{* *}}\end{array}$ & $\begin{array}{c}-0.109 \\
{[0.008]^{* *}}\end{array}$ & $\begin{array}{c}-0.154 \\
{[0.008]^{* *}}\end{array}$ & $\begin{array}{c}-0.172 \\
{[0.008]^{* *}}\end{array}$ & $\begin{array}{c}-0.172 \\
{[0.008]^{* *}}\end{array}$ & $\begin{array}{c}-0.159 \\
{[0.008]^{* *}}\end{array}$ & $\begin{array}{c}-0.16 \\
{[0.008]^{* *}}\end{array}$ \\
\hline No Qual & $\begin{array}{c}-0.349 \\
{[0.013]^{* *}}\end{array}$ & $\begin{array}{c}-0.386 \\
{[0.013]^{* *}}\end{array}$ & $\begin{array}{c}-0.391 \\
{[0.011]^{* *}}\end{array}$ & $\begin{array}{c}-0.417 \\
{[0.011]^{* *}}\end{array}$ & $\begin{array}{c}-0.467 \\
{[0.011]^{* *}}\end{array}$ & $\begin{array}{c}-0.43 \\
{[0.011]^{* *}}\end{array}$ & $\begin{array}{c}-0.47 \\
{[0.011]^{* *}}\end{array}$ & $\begin{array}{c}-0.48 \\
{[0.010]^{* *}}\end{array}$ & $\begin{array}{c}-0.474 \\
{[0.010]^{* *}}\end{array}$ & $\begin{array}{c}-0.479 \\
{[0.010]^{* *}}\end{array}$ & $\begin{array}{c}-0.498 \\
{[0.010]^{* *}}\end{array}$ \\
\hline Black & $\begin{array}{c}-0.118 \\
{[0.017]^{* *}}\end{array}$ & $\begin{array}{c}-0.061 \\
{[0.016]^{* *}}\end{array}$ & $\begin{array}{c}-0.097 \\
{[0.014]^{* *}}\end{array}$ & $\begin{array}{c}-0.12 \\
{[0.014]^{* *}}\end{array}$ & $\begin{array}{c}-0.073 \\
{[0.014]^{* *}}\end{array}$ & $\begin{array}{c}-0.062 \\
{[0.014]^{* *}}\end{array}$ & $\begin{array}{c}-0.074 \\
{[0.014]^{* *}}\end{array}$ & $\begin{array}{c}-0.084 \\
{[0.014]^{* *}}\end{array}$ & $\begin{array}{c}-0.037 \\
{[0.013]^{* *}}\end{array}$ & $\begin{array}{c}-0.055 \\
{[0.014]^{* *}}\end{array}$ & $\begin{array}{c}-0.037 \\
{[0.014]^{* *}}\end{array}$ \\
\hline Asian & $\begin{array}{c}-0.054 \\
{[0.020]^{* *}}\end{array}$ & $\begin{array}{c}-0.041 \\
{[0.020]^{*}}\end{array}$ & $\begin{array}{c}-0.059 \\
{[0.020]^{* *}}\end{array}$ & $\begin{array}{c}-0.13 \\
{[0.022]^{* *}}\end{array}$ & $\begin{array}{c}-0.093 \\
{[0.019]^{* *}}\end{array}$ & $\begin{array}{c}-0.1 \\
{[0.020]^{* *}}\end{array}$ & $\begin{array}{c}-0.142 \\
{[0.019]^{* *}}\end{array}$ & $\begin{array}{c}-0.099 \\
{[0.018]^{* *}}\end{array}$ & $\begin{array}{c}-0.107 \\
{[0.018]^{* *}}\end{array}$ & $\begin{array}{c}-0.104 \\
{[0.017]^{* *}}\end{array}$ & $\begin{array}{c}-0.061 \\
{[0.015]^{* *}}\end{array}$ \\
\hline Other Ethn. & $\begin{array}{c}-0.251 \\
{[0.043]^{* *}}\end{array}$ & $\begin{array}{c}-0.101 \\
{[0.043]^{*}}\end{array}$ & $\begin{array}{c}-0.104 \\
{[0.037]^{* *}}\end{array}$ & $\begin{array}{c}-0.145 \\
{[0.038]^{* *}}\end{array}$ & $\begin{array}{c}-0.038 \\
{[0.034]}\end{array}$ & $\begin{array}{c}-0.095 \\
{[0.032]^{* *}}\end{array}$ & $\begin{array}{c}-0.115 \\
{[0.034]^{* *}}\end{array}$ & $\begin{array}{c}-0.15 \\
{[0.033]^{* *}}\end{array}$ & $\begin{array}{c}-0.035 \\
{[0.018]^{*}}\end{array}$ & $\begin{array}{c}-0.132 \\
{[0.020]^{* *}}\end{array}$ & $\begin{array}{c}-0.089 \\
{[0.019]^{* *}}\end{array}$ \\
\hline Observations & 27322 & 27534 & 36615 & 36975 & 37539 & 38224 & 38382 & 37654 & 40047 & 39137 & 38258 \\
\hline
\end{tabular}

NOTES: We also control for region of residence, age squared and age cubed. The omitted comparison categories are: No Children, High Qualification, Youngest Child 12-16, White. Analysis restricted to those aged 21 years and older. The coefficients and standard errors (in parenthesis) are reported. ${ }^{* *}$ represents significance at the $1 \%$ level, ${ }^{*}$ represents significance at the $5 \%$ level and ${ }^{+}$ represents significance at the $10 \%$ level. 
TABLE A.3: Employment - Number of Children Marginal Effect (1993-2003)

\begin{tabular}{|c|c|c|c|c|c|c|c|c|c|c|c|}
\hline & 1993 & 1994 & 1995 & 1996 & 1997 & 1998 & 1999 & 2000 & 2001 & 2002 & 2003 \\
\hline \multirow[t]{2}{*}{ One Child } & -0.323 & -0.314 & -0.319 & -0.32 & -0.305 & -0.314 & -0.276 & -0.234 & -0.241 & -0.236 & -0.249 \\
\hline & {$[0.009]^{* *}$} & {$[0.008]^{* *}$} & {$[0.007]^{* *}$} & {$[0.007]^{* *}$} & {$[0.007]^{* *}$} & {$[0.007]^{* *}$} & {$[0.007]^{* *}$} & {$[0.007]^{* *}$} & {$[0.007]^{* *}$} & {$[0.007]^{* *}$} & {$[0.007]^{* *}$} \\
\hline \multirow[t]{2}{*}{ Two Children } & -0.471 & -0.531 & -0.481 & -0.429 & -0.421 & -0.448 & -0.398 & -0.361 & -0.354 & -0.356 & -0.374 \\
\hline & {$[0.013]^{* *}$} & {$[0.011]^{* *}$} & {$[0.010]^{* *}$} & {$[0.010]^{* *}$} & {$[0.010]^{* *}$} & {$[0.009]^{* *}$} & {$[0.009]^{* *}$} & {$[0.009]^{* *}$} & {$[0.009]^{* *}$} & {$[0.009]^{* *}$} & {$[0.009]^{* *}$} \\
\hline \multirow[t]{2}{*}{ 3+ Children } & -0.518 & -0.547 & -0.549 & -0.575 & -0.532 & -0.558 & -0.539 & -0.487 & -0.499 & -0.506 & -0.55 \\
\hline & {$[0.019]^{* *}$} & {$[0.016]^{* *}$} & {$[0.013]^{* *}$} & {$[0.012]^{* *}$} & {$[0.013]^{* *}$} & {$[0.012]^{* *}$} & {$[0.013]^{* *}$} & {$[0.013]^{* *}$} & {$[0.012]^{* *}$} & {$[0.013]^{* *}$} & {$[0.012]^{* *}$} \\
\hline \multirow[t]{2}{*}{ Age } & -0.04 & -0.012 & -0.014 & 0.008 & 0.021 & 0.047 & 0.021 & 0.021 & 0.013 & 0.005 & 0.021 \\
\hline & {$[0.010] * *$} & [0.010] & [0.009] & [0.009] & {$[0.009]^{*}$} & {$[0.008]^{* *}$} & {$[0.008]^{*}$} & {$[0.008]^{* *}$} & {$[0.008]+$} & {$[0.008]$} & {$[0.008]^{* *}$} \\
\hline \multirow[t]{2}{*}{ Medium Qual } & 0.009 & -0.006 & -0.003 & -0.031 & -0.05 & -0.005 & -0.05 & -0.052 & -0.063 & -0.046 & -0.035 \\
\hline & {$[0.010]$} & [0.011] & [0.009] & {$[0.009]^{* *}$} & {$[0.009]^{* *}$} & [0.008] & {$[0.008]^{* *}$} & {$[0.008]^{* *}$} & {$[0.008]^{* *}$} & {$[0.007]^{* *}$} & {$[0.007]^{* *}$} \\
\hline \multirow[t]{2}{*}{ Low Qual } & -0.079 & -0.098 & -0.094 & -0.124 & -0.159 & -0.114 & -0.158 & -0.175 & -0.178 & -0.157 & -0.154 \\
\hline & {$[0.011]^{* *}$} & {$[0.011]^{* *}$} & {$[0.009]^{* *}$} & {$[0.009]^{* *}$} & {$[0.009]^{* *}$} & {$[0.008]^{* *}$} & {$[0.008]^{* *}$} & {$[0.008]^{* *}$} & {$[0.008]^{* *}$} & {$[0.008]^{* *}$} & {$[0.008]^{* *}$} \\
\hline \multirow[t]{2}{*}{ No Qual } & -0.353 & -0.383 & -0.385 & -0.409 & -0.456 & -0.417 & -0.461 & -0.472 & -0.464 & -0.461 & -0.481 \\
\hline & {$[0.013]^{* *}$} & {$[0.013]^{* *}$} & {$[0.011]^{* *}$} & {$[0.011]^{* *}$} & {$[0.011]^{* *}$} & {$[0.011]^{* *}$} & {$[0.011]^{* *}$} & {$[0.011]^{* *}$} & {$[0.010]^{* *}$} & {$[0.011]^{* *}$} & {$[0.011]^{* *}$} \\
\hline \multirow[t]{2}{*}{ Black } & -0.106 & -0.042 & -0.09 & -0.102 & -0.064 & -0.068 & -0.074 & -0.084 & -0.046 & -0.065 & -0.041 \\
\hline & {$[0.017]^{* *}$} & {$[0.015]^{* *}$} & {$[0.014]^{* *}$} & {$[0.014]^{* *}$} & {$[0.014]^{* *}$} & {$[0.014]^{* *}$} & {$[0.014]^{* *}$} & {$[0.014]^{* *}$} & {$[0.014]^{* *}$} & {$[0.014]^{* *}$} & {$[0.014]^{* *}$} \\
\hline \multirow[t]{2}{*}{ Asian } & -0.038 & -0.041 & -0.051 & -0.086 & -0.075 & -0.078 & -0.129 & -0.085 & -0.083 & -0.091 & -0.073 \\
\hline & {$[0.020]+$} & {$[0.020]^{*}$} & {$[0.020]^{*}$} & {$[0.021]^{* *}$} & {$[0.019]^{* *}$} & {$[0.019] * *$} & {$[0.019]^{* *}$} & {$[0.018]^{* *}$} & {$[0.017]^{* *}$} & {$[0.016]^{* *}$} & {$[0.016]^{* *}$} \\
\hline \multirow[t]{2}{*}{ Other Ethn. } & -0.251 & -0.107 & -0.085 & -0.145 & -0.035 & -0.083 & -0.101 & -0.131 & -0.023 & -0.125 & -0.09 \\
\hline & {$[0.043]^{* *}$} & {$[0.042]^{*}$} & {$[0.036]^{*}$} & {$[0.038]^{* *}$} & [0.033] & {$[0.031]^{* *}$} & {$[0.034]^{* *}$} & {$[0.033]^{* *}$} & {$[0.018]$} & {$[0.020]^{* *}$} & {$[0.019]^{* *}$} \\
\hline Observations & 27322 & 27534 & 36615 & 36865 & 37391 & 38092 & 38245 & 37449 & 39791 & 38881 & 37996 \\
\hline
\end{tabular}

NOTES: We also control for region of residence, age squared and age cubed. The omitted comparison categories are: No Children, High Qualification, Youngest Child 12-16, White. Analysis restricted to those aged 21 years and older. The coefficients and standard errors (in parenthesis) are reported. ** represents significance at the $1 \%$ level, * represents significance at the $5 \%$ level and ${ }^{+}$ represents significance at the $10 \%$ level. 
TABLE A.4.: Employment - Differential Qualification Marginal Effect (1993-2003)

\begin{tabular}{|c|c|c|c|c|c|c|c|c|c|c|c|}
\hline & 1993 & 1994 & 1995 & 1996 & 1997 & 1998 & 1999 & 2000 & 2001 & 2002 & 2003 \\
\hline Child & $\begin{array}{c}-0.14 \\
{[0.039]^{* *}}\end{array}$ & $\begin{array}{c}-0.153 \\
{[0.039]^{* *}}\end{array}$ & $\begin{array}{c}-0.167 \\
{[0.025]^{* *}}\end{array}$ & $\begin{array}{c}-0.178 \\
{[0.022]^{* *}}\end{array}$ & $\begin{array}{c}-0.172 \\
{[0.021]^{* *}}\end{array}$ & $\begin{array}{c}-0.236 \\
{[0.018]^{* *}}\end{array}$ & $\begin{array}{c}-0.238 \\
{[0.018]^{* *}}\end{array}$ & $\begin{array}{c}-0.167 \\
{[0.017]^{* *}}\end{array}$ & $\begin{array}{c}-0.185 \\
{[0.016]^{* *}}\end{array}$ & $\begin{array}{c}-0.168 \\
{[0.016]^{* *}}\end{array}$ & $\begin{array}{c}-0.18 \\
{[0.016]^{* *}}\end{array}$ \\
\hline Medium Qual & $\begin{array}{c}0.011 \\
{[0.011]}\end{array}$ & $\begin{array}{c}-0.014 \\
{[0.011]}\end{array}$ & $\begin{array}{l}-0.008 \\
{[0.010]}\end{array}$ & $\begin{array}{c}-0.031 \\
{[0.009]^{* *}}\end{array}$ & $\begin{array}{c}-0.039 \\
{[0.009]^{* *}}\end{array}$ & $\begin{array}{c}-0.004 \\
{[0.009]}\end{array}$ & $\begin{array}{c}-0.046 \\
{[0.009]^{* *}}\end{array}$ & $\begin{array}{c}-0.037 \\
{[0.009]^{* *}}\end{array}$ & $\begin{array}{c}-0.052 \\
{[0.009]^{* *}}\end{array}$ & $\begin{array}{c}-0.029 \\
{[0.008]^{* *}}\end{array}$ & $\begin{array}{c}-0.023 \\
{[0.008]^{* *}}\end{array}$ \\
\hline Low Qual & $\begin{array}{c}-0.048 \\
{[0.011]^{* *}}\end{array}$ & $\begin{array}{c}-0.065 \\
{[0.011]^{* *}}\end{array}$ & $\begin{array}{c}-0.044 \\
{[0.009]^{* *}}\end{array}$ & $\begin{array}{c}-0.073 \\
{[0.009]^{* *}}\end{array}$ & $\begin{array}{c}-0.105 \\
{[0.010]^{* *}}\end{array}$ & $\begin{array}{c}-0.067 \\
{[0.009]^{* *}}\end{array}$ & $\begin{array}{c}-0.126 \\
{[0.010]^{* *}}\end{array}$ & $\begin{array}{c}-0.135 \\
{[0.010]^{* *}}\end{array}$ & $\begin{array}{c}-0.137 \\
{[0.010]^{* *}}\end{array}$ & $\begin{array}{c}-0.12 \\
{[0.009]^{* *}}\end{array}$ & $\begin{array}{c}-0.118 \\
{[0.009]^{* *}}\end{array}$ \\
\hline No Qual & $\begin{array}{c}-0.356 \\
{[0.014]^{* *}}\end{array}$ & $\begin{array}{c}-0.391 \\
{[0.014]^{* *}}\end{array}$ & $\begin{array}{c}-0.38 \\
{[0.013]^{* *}}\end{array}$ & $\begin{array}{c}-0.407 \\
{[0.013]^{* *}}\end{array}$ & $\begin{array}{c}-0.479 \\
{[0.013]^{* *}}\end{array}$ & $\begin{array}{c}-0.453 \\
{[0.013]^{* *}}\end{array}$ & $\begin{array}{c}-0.501 \\
{[0.013]^{* *}}\end{array}$ & $\begin{array}{c}-0.512 \\
{[0.013]^{* *}}\end{array}$ & $\begin{array}{c}-0.514 \\
{[0.012]^{* *}}\end{array}$ & $\begin{array}{c}-0.508 \\
{[0.013]^{* *}}\end{array}$ & $\begin{array}{c}-0.535 \\
{[0.013]^{* *}}\end{array}$ \\
\hline Med Qual*Child & $\begin{array}{c}-0.168 \\
{[0.045]^{* *}}\end{array}$ & $\begin{array}{c}-0.138 \\
{[0.044]^{* *}}\end{array}$ & $\begin{array}{c}-0.096 \\
{[0.028]^{* *}}\end{array}$ & $\begin{array}{c}-0.093 \\
{[0.025]^{* *}}\end{array}$ & $\begin{array}{c}-0.123 \\
{[0.025]^{* *}}\end{array}$ & $\begin{array}{c}-0.068 \\
{[0.020]^{* *}}\end{array}$ & $\begin{array}{c}-0.047 \\
{[0.019]^{*}}\end{array}$ & $\begin{array}{c}-0.095 \\
{[0.021]^{* *}}\end{array}$ & $\begin{array}{c}-0.077 \\
{[0.019]^{* *}}\end{array}$ & $\begin{array}{c}-0.102 \\
{[0.019]^{* *}}\end{array}$ & $\begin{array}{c}-0.102 \\
{[0.019]^{* *}}\end{array}$ \\
\hline Low Qual*Child & $\begin{array}{c}-0.276 \\
{[0.044]^{* *}}\end{array}$ & $\begin{array}{c}-0.284 \\
{[0.044]^{* *}}\end{array}$ & $\begin{array}{c}-0.279 \\
{[0.029]^{* *}}\end{array}$ & $\begin{array}{c}-0.248 \\
{[0.026]^{* *}}\end{array}$ & $\begin{array}{c}-0.231 \\
{[0.025]^{* *}}\end{array}$ & $\begin{array}{c}-0.183 \\
{[0.022]^{* *}}\end{array}$ & $\begin{array}{c}-0.114 \\
{[0.021]^{* *}}\end{array}$ & $\begin{array}{c}-0.153 \\
{[0.021]^{* *}}\end{array}$ & $\begin{array}{c}-0.141 \\
{[0.020]^{* *}}\end{array}$ & $\begin{array}{c}-0.149 \\
{[0.020]^{* *}}\end{array}$ & $\begin{array}{c}-0.161 \\
{[0.020]^{* *}}\end{array}$ \\
\hline No Qual*Child & $\begin{array}{c}-0.191 \\
{[0.045]^{* *}}\end{array}$ & $\begin{array}{c}-0.199 \\
{[0.045]^{* *}}\end{array}$ & $\begin{array}{c}-0.186 \\
{[0.031]^{* *}}\end{array}$ & $\begin{array}{c}-0.158 \\
{[0.028]^{* *}}\end{array}$ & $\begin{array}{c}-0.089 \\
{[0.025]^{* *}}\end{array}$ & $\begin{array}{c}-0.038 \\
{[0.021]^{+}}\end{array}$ & $\begin{array}{c}-0.002 \\
{[0.020]}\end{array}$ & $\begin{array}{c}-0.025 \\
{[0.021]}\end{array}$ & $\begin{array}{c}0 \\
{[0.019]}\end{array}$ & $\begin{array}{c}-0.018 \\
{[0.019]}\end{array}$ & $\begin{array}{c}-0.005 \\
{[0.019]}\end{array}$ \\
\hline Age & $\begin{array}{c}-0.045 \\
{[0.010]^{* *}}\end{array}$ & $\begin{array}{c}-0.022 \\
{[0.010]^{*}}\end{array}$ & $\begin{array}{r}-0.0 \\
{[0.00}\end{array}$ & $\begin{array}{r}0.0 \\
{[0.0}\end{array}$ & $\begin{array}{c}0.016 \\
{[0.008]+}\end{array}$ & $\begin{array}{c}0.034 \\
{[0.008]^{* *}}\end{array}$ & $\begin{array}{c}0.01 \\
{[0.008]}\end{array}$ & $\begin{array}{c}0.012 \\
{[0.008]}\end{array}$ & $\begin{array}{c}0.004 \\
{[0.008]}\end{array}$ & $\begin{array}{c}-0.007 \\
{[0.008]}\end{array}$ & $\begin{array}{c}0.004 \\
{[0.008]}\end{array}$ \\
\hline Bla & $\begin{array}{c}-0.119 \\
{[0.017]^{* *}}\end{array}$ & $\begin{array}{c}-0.053 \\
{[0.015]^{* *}}\end{array}$ & $\begin{array}{c}-0.089 \\
{[0.014]^{* *}}\end{array}$ & $\begin{array}{c}-0.114 \\
{[0.014]^{* *}}\end{array}$ & $\begin{array}{c}-0.068 \\
{[0.014]^{* *}}\end{array}$ & $\begin{array}{c}-0.071 \\
{[0.014]^{* *}}\end{array}$ & $\begin{array}{c}-0.078 \\
{[0.014]^{* *}}\end{array}$ & $\begin{array}{c}-0.09 \\
{[0.014]^{* *}}\end{array}$ & $\begin{array}{c}-0.045 \\
{[0.014]^{* *}}\end{array}$ & $\begin{array}{c}-0.066 \\
{[0.014]^{* *}}\end{array}$ & $\begin{array}{c}-0.045 \\
{[0.014]^{* *}}\end{array}$ \\
\hline Asian & $\begin{array}{c}-0.051 \\
{[0.020]^{*}}\end{array}$ & $\begin{array}{c}-0.048 \\
{[0.020]^{*}}\end{array}$ & $\begin{array}{c}-0.053 \\
{[0.020]^{* *}}\end{array}$ & $\begin{array}{c}-0.102 \\
{[0.021]^{* *}}\end{array}$ & $\begin{array}{c}-0.082 \\
{[0.019]^{* *}}\end{array}$ & $\begin{array}{c}-0.086 \\
{[0.019]^{* *}}\end{array}$ & $\begin{array}{c}-0.135 \\
{[0.019]^{* *}}\end{array}$ & $\begin{array}{c}-0.085 \\
{[0.018]^{* *}}\end{array}$ & $\begin{array}{c}-0.089 \\
{[0.017]^{* *}}\end{array}$ & $\begin{array}{c}-0.094 \\
{[0.016] * *}\end{array}$ & $\begin{array}{c}-0.075 \\
{[0.016]^{* *}}\end{array}$ \\
\hline Other Ethn. & $\begin{array}{c}-0.245 \\
{[0.043]^{* *}}\end{array}$ & $\begin{array}{c}-0.109 \\
{[0.042]^{* *}}\end{array}$ & $\begin{array}{c}-0.083 \\
{[0.036]^{*}}\end{array}$ & $\begin{array}{c}-0.145 \\
{[0.038]^{* *}}\end{array}$ & $\begin{array}{l}-0.046 \\
{[0.034]}\end{array}$ & $\begin{array}{c}-0.088 \\
{[0.031]^{* *}}\end{array}$ & $\begin{array}{c}-0.106 \\
{[0.034]^{* *}}\end{array}$ & $\begin{array}{c}-0.131 \\
{[0.033]^{* *}}\end{array}$ & $\begin{array}{c}-0.033 \\
{[0.018]+}\end{array}$ & $\begin{array}{c}-0.125 \\
{[0.020]^{* *}}\end{array}$ & $\begin{array}{c}-0.088 \\
{[0.019]^{* *}}\end{array}$ \\
\hline Observations & 27322 & 27534 & 36615 & 36975 & 37539 & 38224 & 38382 & 37654 & 40047 & 39137 & 38258 \\
\hline
\end{tabular}

NOTES: We also control for region of residence, age squared and age cubed. The omitted comparison categories are: No Children, High Qualification, Youngest Child 12-16, White. Analysis restricted to those aged 21 years and older. The coefficients and standard errors (in parenthesis) are reported. ** represents significance at the $1 \%$ level, * represents significance at the $5 \%$ level and ${ }^{+}$represents significance at the $10 \%$ level. 
Figure A1: Employment Rate of Lone Mothers and Single (Childless Low Edu) Women

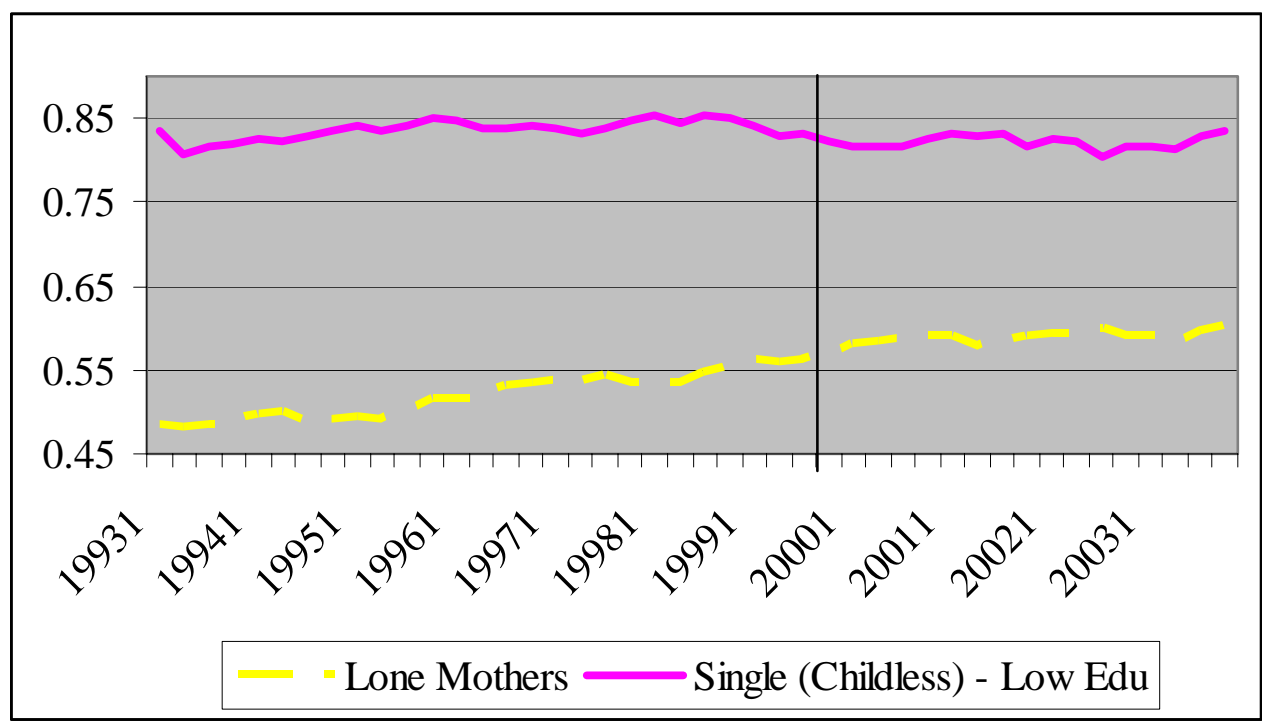

Figure 2.A2: Employment Rate of Lone Mothers (Low Edu) and Single (Childless Low Edu) Women

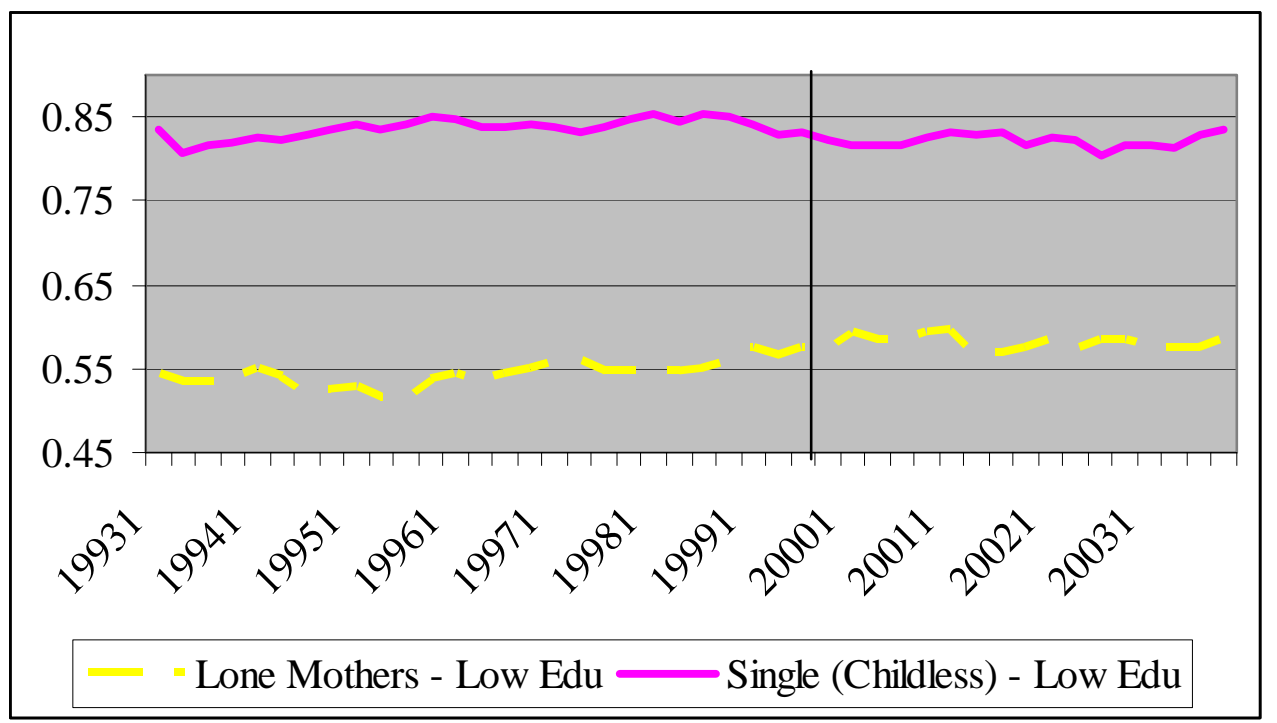

